\title{
Reviews and syntheses: Anthropogenic perturbations to carbon fluxes in Asian river systems - concepts, emerging trends, and research challenges
}

\author{
Ji-Hyung Park ${ }^{1}$, Omme K. Nayna ${ }^{1}$, Most S. Begum ${ }^{1}$, Eliyan Chea ${ }^{2}$, Jens Hartmann ${ }^{3}$, Richard G. Keil ${ }^{4}$, \\ Sanjeev Kumar ${ }^{5}$, Xixi Lu ${ }^{6}$, Lishan Ran ${ }^{7}$, Jeffrey E. Richey ${ }^{4}$, Vedula V. S. S. Sarma ${ }^{8}$, Shafi M. Tareq ${ }^{9}$, Do Thi Xuan ${ }^{10}$, \\ and Ruihong Yu ${ }^{11}$ \\ ${ }^{1}$ Department of Environmental Science and Engineering, Ewha Womans University, Seoul, 03760, Republic of Korea \\ ${ }^{2}$ Department of Environmental Science, Royal University of Phnom Penh, Phnom Penh, Cambodia \\ ${ }^{3}$ Institute for Geology, Universität Hamburg, Hamburg, Germany \\ ${ }^{4}$ School of Oceanography, University of Washington, Seattle, 98112, USA \\ ${ }^{5}$ Geosciences Division, Physical Research Laboratory, Ahmedabad, 380009, India \\ ${ }^{6}$ Department of Geography, National University of Singapore, Singapore \\ ${ }^{7}$ Department of Geography, University of Hong Kong, Pokfulam Road, Hong Kong \\ ${ }^{8}$ National Institute of Oceanography, Council of Scientific and Industrial Research, Visakhapatnam, India \\ ${ }^{9}$ Department of Environmental Sciences, Jahangirnagar University, Dhaka, 1342, Bangladesh \\ ${ }^{10}$ Department of Soil Science, Cantho University, Cantho, Vietnam \\ ${ }^{11}$ College of Environment and Resources, University of Inner Mongolia, Hohhot, China
}

Correspondence: Ji-Hyung Park (jhp@ewha.ac.kr)

Received: 19 December 2017 - Discussion started: 16 January 2018

Revised: 25 April 2018 - Accepted: 26 April 2018 - Published: 17 May 2018

\begin{abstract}
Human activities are drastically altering water and material flows in river systems across Asia. These anthropogenic perturbations have rarely been linked to the carbon (C) fluxes of Asian rivers that may account for up to $40-50 \%$ of the global fluxes. This review aims to provide a conceptual framework for assessing the human impacts on Asian river $\mathrm{C}$ fluxes, along with an update on anthropogenic alterations of riverine $\mathrm{C}$ fluxes. Drawing on case studies conducted in three selected rivers (the Ganges, Mekong, and Yellow River) and other major Asian rivers, the review focuses on the impacts of river impoundment and pollution on $\mathrm{CO}_{2}$ outgassing from the rivers draining South, Southeast, and East Asian regions that account for the largest fraction of river discharge and $\mathrm{C}$ exports from Asia and Oceania. A critical examination of major conceptual models of riverine processes against observed trends suggests that to better understand altered metabolisms and $\mathrm{C}$ fluxes in "anthropogenic land-water-scapes", or riverine landscapes modified by human activities, the traditional view of the river continuum should be complemented with concepts address-
\end{abstract}

ing spatial and temporal discontinuities created by human activities, such as river impoundment and pollution. Recent booms in dam construction on many large Asian rivers pose a host of environmental problems, including increased retention of sediment and associated C. A small number of studies that measured greenhouse gas (GHG) emissions in dammed Asian rivers have reported contrasting impoundment effects: decreased GHG emissions from eutrophic reservoirs with enhanced primary production vs. increased emissions from the flooded vegetation and soils in the early years following dam construction or from the impounded reaches and downstream estuaries during the monsoon period. These contrasting results suggest that the rates of metabolic processes in the impounded and downstream reaches can vary greatly longitudinally over time as a combined result of diel shifts in the balance between autotrophy and heterotrophy, seasonal fluctuations between dry and monsoon periods, and a long-term change from a leaky post-construction phase to a gradual C sink. The rapid pace of urbanization across southern and eastern Asian regions has dramatically increased municipal wa- 
ter withdrawal, generating annually $120 \mathrm{~km}^{3}$ of wastewater in 24 countries, which comprises $39 \%$ of the global municipal wastewater production. Although municipal wastewater constitutes only $1 \%$ of the renewable surface water, it can disproportionately affect the receiving river water, particularly downstream of rapidly expanding metropolitan areas, resulting in eutrophication, increases in the amount and lability of organic $\mathrm{C}$, and pulse emissions of $\mathrm{CO}_{2}$ and other GHGs. In rivers draining highly populated metropolitan areas, lower reaches and tributaries, which are often plagued by frequent algal blooms and pulsatile $\mathrm{CO}_{2}$ emissions from urban tributaries delivering high loads of wastewater, tended to exhibit higher levels of organic $\mathrm{C}$ and the partial pressure of $\mathrm{CO}_{2}\left(p \mathrm{CO}_{2}\right)$ than less impacted upstream reaches and eutrophic impounded reaches. More field measurements of $p \mathrm{CO}_{2}$, together with accurate flux calculations based on river-specific model parameters, are required to provide more accurate estimates of GHG emissions from the Asian rivers that are now underrepresented in the global $\mathrm{C}$ budgets. The new conceptual framework incorporating discontinuities created by impoundment and pollution into the river continuum needs to be tested with more field measurements of riverine metabolisms and $\mathrm{CO}_{2}$ dynamics across variously affected reaches to better constrain altered fluxes of organic $\mathrm{C}$ and $\mathrm{CO}_{2}$ resulting from changes in the balance between autotrophy and heterotrophy in increasingly human-modified river systems across Asia and other continents.

\section{Introduction}

Inland waters play a pivotal role in the global carbon (C) cycle by storing, transporting, or transforming inorganic and organic C components along the hydrologic continuum linking the land and oceans (Kempe, 1982, 1984; Cole et al., 2007; Battin et al., 2009). Recent syntheses have provided greater estimates for the riverine transport of dissolved organic $\mathrm{C}$ (DOC) and particulate organic C (POC) and the exchange of $\mathrm{CO}_{2}$ between the atmosphere and inland waters than previous studies (Raymond et al., 2013; Regnier et al., 2013; Wehrli, 2013; Ward et al., 2017). Monitoring data are sparse for many river systems in Asia and Africa, leaving many blind spots in global syntheses of riverine $\mathrm{C}$ transport and emission. Although Asian rivers have been estimated to account for up to $40-50 \%$ of the global inorganic and organic C fluxes from the land to the oceans (Degens et al., 1991; Ludwig et al., 1996; Schlünz and Schneider, 2000; Dai et al., 2012), the lack of high-quality data and poor spatial coverage have constrained our ability to estimate the contributions of Asian river systems to the global riverine $\mathrm{C}$ fluxes in general and $\mathrm{CO}_{2}$ outgassing in particular (Schlünz and Schneider, 2000; Lauerwald et al., 2015; Li and Bush, 2015a, b). For instance, obtaining $p \mathrm{CO}_{2}$ data measured in Southeast Asian rivers was suggested as a top priority to reduce the large uncertainty in estimating the global riverine $\mathrm{CO}_{2}$ outgassing (Lauerwald et al., 2015).

The release of $\mathrm{C}$ from anthropogenic sources in rapidly urbanizing watersheds around the world increases the uncertainty of the current global riverine C flux estimates (Regnier et al., 2013). Concurrent anthropogenic perturbations to the river systems, including eutrophication, altered sediment regimes, and increased water residence time in impounded rivers, can significantly change the riverine processing of organic matter (OM) and greenhouse gas (GHG) outgassing (Stanley et al., 2012; Regnier et al., 2013; Crawford et al., 2016). Many streams and rivers across Asia are highly polluted by agricultural runoff and domestic and industrial wastewater, with their water quality often exhibiting large seasonal variations associated with regional monsoon rainfall regimes (Park et al., 2010, 2011; Evans et al., 2012, Bhatt et al., 2014). Although enhanced lability and mineralization of organic $\mathrm{C}$ have been observed in streams and rivers draining urbanized watersheds (Hosen et al., 2014; Kaushal et al., 2014), little is known about organic $\mathrm{C}$ export and $\mathrm{CO}_{2}$ outgassing from streams and rivers draining rapidly urbanizing watersheds in developing Asian countries (Bhatt et al., 2014). A few recent studies conducted in the metropolitan areas of China and Korea have suggested that GHG emissions from polluted waterways carrying urban runoff and wastewater treatment plant (WWTF) effluents may be underappreciated as sources of GHGs (Wang et al., 2017; Yoon et al., 2017). Despite recent booms in the construction of large dams on many large rivers across the region, little attention has been paid to impoundment effects on GHG emissions (Chen et al., 2009; Hu and Cheng, 2013). Considering the role of dams in storing huge amounts of sediment and organic C (Syvitski et al., 2005; Maavara et al., 2017), a mechanistic understanding of GHG emissions from impounded rivers can provide more insights into the anthropogenic perturbations to the $\mathrm{C}$ fluxes of dammed river systems.

This review aims to provide a conceptual framework for assessing the human impacts on riverine $\mathrm{C}$ fluxes and an update on major anthropogenic perturbations affecting $C$ fluxes in Asian river systems, focusing on the impacts of water pollution and river impoundments on riverine $\mathrm{CO}_{2}$ dynamics in South (S), Southeast (SE), and East (E) Asian regions that account for the largest fraction of river discharge and $\mathrm{C}$ exports from Asia and Oceania (Fig. 1). An important goal was to integrate various concepts of riverine biogeochemical processes into a conceptual framework for assessing human impacts on the riverine $\mathrm{C}$ fluxes in human-modified river systems. Given the pace and wide-ranging impacts of urbanization and river impoundments, the traditional view of the river continuum developed for natural streams and rivers (Vannote et al., 1980) needs to be revised to reflect altered regimes of riverine metabolic processes and material fluxes. We compared reported values of $p \mathrm{CO}_{2}$ that had been either measured or estimated for major river basins in three Asian regions, including the Ganges, the Mekong, and the Yellow River as 


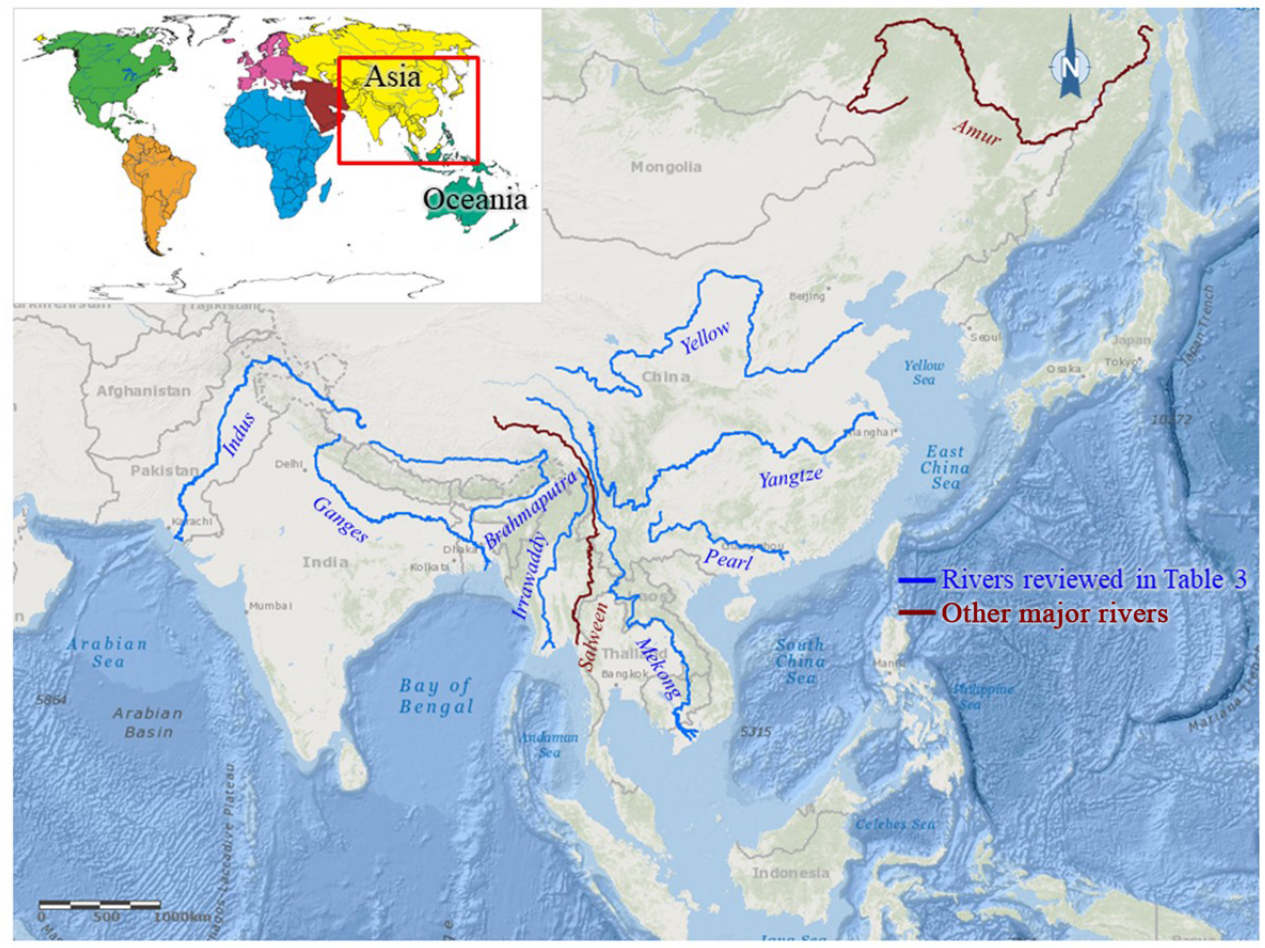

Figure 1. Major river systems of South, Southeast, and East Asia that belong to top 30 global rivers based on discharge (Raymond and Spencer, 2015). The base map and the inset world map were modified from the ArcGIS online Ocean Basemap and Milliman and Farnsworth (2011), respectively. Rivers addressed in the review and other large rivers are distinguished by different colors. Three Asian regions comprise the majority of Asian countries included in the regional categories "Asia" (indicated by yellow on the inset world map) and "Oceania" (dark green) used by Milliman and Farnsworth (2011).

representative systems of three regions, to assess the current status. We also compared $p \mathrm{CO}_{2}$ values among different components of the river basin (main stem, headwater, tributary, and impoundment) to examine how water pollution and impoundments alter riverine metabolic processes and $\mathrm{CO}_{2}$ emissions. Many of the reported values have been estimated from $\mathrm{pH}$ and alkalinity data available from the literature and water quality databases such as GLORICH (Global River Chemistry Database; Hartmann et al., 2014). Considering potential overestimations of water $p \mathrm{CO}_{2}$ associated with organic acid contributions and increased sensitivity to alkalinity in acidic, organic-rich waters with low carbonate buffering (Abril et al., 2015), we provided methodological details for the calculated $p \mathrm{CO}_{2}$ values if the cited references considered these $\mathrm{pH}$ and alkalinity effects. This review and the following synthesis efforts are expected to provide scientifically robust conceptual frameworks and data that are required for a better understanding of how human-induced perturbations in rapidly urbanizing watersheds across Asia transform riverine metabolic processes and C fluxes away from the "natural" states assumed in the traditional river continuum model.

\section{The geographical scope, global implications, and emerging regional trends of Asian river systems}

Global syntheses of riverine $\mathrm{C}$ fluxes have been based on monitoring data available for a limited number of large rivers (e.g., Degens et al., 1991; Ludwig et al., 1996). We referred to these previous syntheses and a more recent synthesis of global river discharge (Milliman and Farnsworth, 2011) to scope the geographical extent of Asian river systems. We followed the continental categories used by Milliman and Farnsworth (2011), namely Asia and Oceania demarcated in Fig. 1, but did not consider Arctic rivers in Russia and rivers in Australia and New Zealand. This review focuses on $\mathrm{S}, \mathrm{SE}$, and $\mathrm{E}$ Asian regions where river systems are commonly affected by increasing human impacts and for which data are available to address major review themes. Ten large rivers in three Asian regions (Fig. 1) belong to top 30 global rivers based on discharge (Raymond and Spencer, 2015), 32 rivers included in a previous global synthesis of riverine C fluxes (Ludwig et al., 1996), or 34 rivers with basin areas greater than $500000 \mathrm{~km}^{2}$ (Milliman and Farnsworth, 2011). The river systems in these Asian regions share some common hydrologic and demographic features (Table 1), including a large seasonality in discharge, 
high population densities $\left(80-513 \mathrm{~km}^{-2}\right)$ compared to the global mean $\left(70 \mathrm{~km}^{-2}\right)$, and a wide range of per capita annual discharge (23-8594 $\mathrm{m}^{3} \mathrm{yr}^{-1}$ person ${ }^{-1}$ vs. the global mean: $4901 \mathrm{~m}^{3} \mathrm{yr}^{-1}$ person $\left.{ }^{-1}\right)$. Large seasonal variations in precipitation and runoff associated with Asian monsoon systems play a critical role in hydrologically mediated riverine processes including those affecting $\mathrm{C}$ fluxes (Park et al., 2010). Recent demographic changes including an unprecedented rapid growth in population may cause increasingly severe perturbations to water and material flows along the rivers that are not only regulated by dams and but are also polluted by urban sewage and agricultural runoff.

According to an earlier estimation (Degens et al., 1991), Asian rivers account for up to 35, 50, and $39 \%$ of the global discharge, total organic C (TOC) export, and dissolved inorganic C (DIC) export. Schlünz and Schneider (2000) provided a lower estimate for TOC export by Asian rivers (175. $2 \mathrm{Tg} \mathrm{C} \mathrm{yr}^{-1} ; 40 \%$ of the global TOC flux). Ludwig et al. (1996) provided separate estimates for the export of

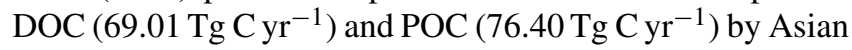
rivers, which represented 34 and $44 \%$ of the corresponding global fluxes, respectively. More recent syntheses of the published data have corroborated the quantitative importance of Asian rivers in the global fluvial C fluxes (Dai et al., 2012; Huang et al., 2012; Galy et al., 2015). As indicated by the lower ratio of DOC to POC (0.9) compared to other regions with the ratio exceeding 1, many Asian rivers draining erosion-prone mountainous terrain deliver more POC than DOC, particularly during the monsoon period (Ittekkot et al., 1988; Ludwig et al., 1996). Monsoonal increases in discharge and POC can have either a positive effect on riverine $p \mathrm{CO}_{2}$ levels through the enhanced soil flushing of DIC and/or in-stream organic $\mathrm{C}$ biodegradation or a negative effect caused by dilution, as observed in such turbid Asian rivers as the Pearl (Yao et al., 2007), Yangtze (Li et al., 2012), and Mekong (Li et al., 2013b). Constraining differential monsoon effects on the fluxes of DOC, POC, and DIC including $\mathrm{CO}_{2}$ represents a key challenge in evaluating the contribution of Asian rivers to the global riverine $\mathrm{C}$ fluxes.

Previous syntheses based on a small number of data sets collected in several large Asian rivers during the 1970s and 1980s provide only limited information when we assess the effects of "ongoing" environmental changes on riverine C fluxes. Therefore, this review aims to provide an update on Asian river $\mathrm{C}$ fluxes, focusing on river impoundment and pollution as two of the most important environmental changes affecting river systems across three target Asian regions. There have been few systematic assessments of the effects of impoundments and water pollution on the $\mathrm{C}$ fluxes of Asian rivers (Sarma et al., 2011; Ran et al., 2014; Li and Bush, 2015a, b). For example, a cascade of dams constructed along the upper Mekong River since the 1990s have been implicated to cause a wide range of downstream impacts including decreases in water and sediment flow ( $\mathrm{Li}$ and Bush, 2015a). Although it is expected that declining sediment flux can sig- (a)

\section{(b)}

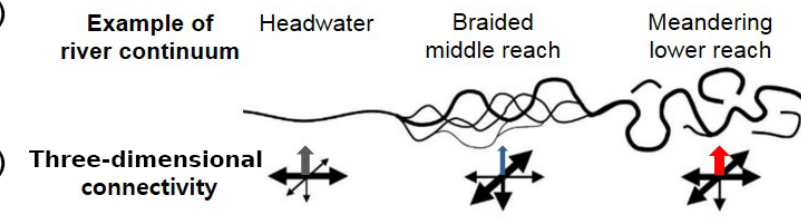

(c)

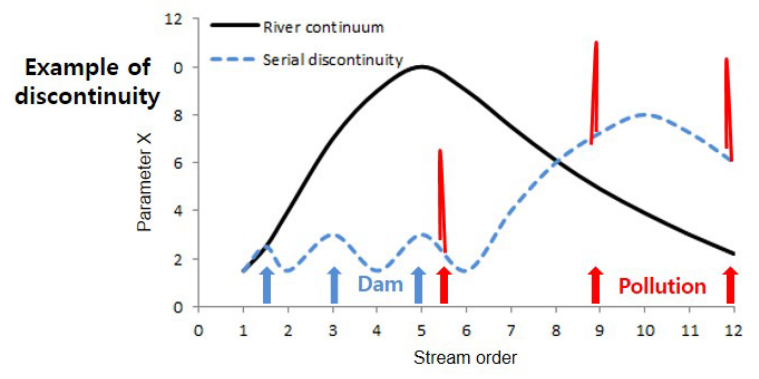

Figure 2. A schematic diagram describing river discontinuity in the anthropogenic land-water-scape: an example of river continuum observed in a minimally impacted river (a); three-dimensional connectivity vectors along the upper, middle, and lower river reaches (b); longitudinal variations in a hypothetical riverine biogeochemical process $X$ (c). The connectivity vectors and the plots depicting river continuum and serial discontinuity were modified from Stanford and Ward (2001) and Poole (2010), complemented with some additional considerations including pollution-induced pulsatile discontinuities (red-colored pulses) and the vertical vector of air-water gas exchange (blue and red, indicating the potential effects of dams and water pollution, respectively).

nificantly alter POC and associated $\mathrm{C}$ fractions along downstream reaches, little is known about impoundment effects on the fluxes of POC, DOC, DIC, and $\mathrm{CO}_{2}$ in the upper and lower Mekong River. This lag between the real-time environmental changes and scientific assessments based on outdated data is quite surprising given the magnitude and pace of the environmental changes occurring across Asia. Deforestation and associated peatland drainage in tropical areas represent another important but rarely explored topic with regard to $\mathrm{CO}_{2}$ outgassing from Asian rivers (Baum et al., 2007; Wit et al., 2015). A recent study suggested that peatland drainage could enhance organic matter degradation in the coastal peatlands and organic-rich soils of Southeast Asian lowland areas and islands, increasing $\mathrm{CO}_{2}$ outgassing from the rivers draining the affected areas (Wit et al., 2015). However, this issue cannot be addressed in detail here because only a few studies have been conducted in Indonesia and Malaysia.

\section{Conceptual framework for understanding interactive effects of changing land-water-scape and climate on riverine $\mathbf{C}$ fluxes}

Human-induced land changes, as manifested in agricultural lands and urban areas, drive changes in biogeochemical cycles and climates, with altered terrestrial biogeochemical cycles often leading to pollution in downstream aquatic sys- 
Table 1. Geographic and demographic features of the major river systems addressed in the review in comparison with Asian and global sums.

\begin{tabular}{|c|c|c|c|c|c|c|c|}
\hline River & Receiving sea & Region & $\begin{array}{l}\text { Basin area } \\
\left(10^{3} \mathrm{~km}^{2}\right)\end{array}$ & $\begin{array}{r}\text { Annual } \\
\text { discharge } \\
\left(\mathrm{km}^{3} \mathrm{yr}^{-1}\right)\end{array}$ & $\begin{array}{l}\text { Population } \\
\qquad\left(\times 10^{6}\right)\end{array}$ & $\begin{array}{r}\text { Population } \\
\text { density } \\
(\text { per km²) }\end{array}$ & $\begin{array}{r}\text { Annual discharge } \\
\text { per capita } \\
\left(\mathrm{m}^{3} \mathrm{yr}^{-1}\right)\end{array}$ \\
\hline Ganges & Bay of Bengal & S Asia & 980 & 490 & 411 & 419 & 1193 \\
\hline Brahmaputra & Bay of Bengal & S Asia & 670 & 630 & 145 & 216 & 4353 \\
\hline Indus & Arabian Sea & S Asia & 980 & $5(90)$ & 220 & 224 & $23(410)$ \\
\hline Krishna & Bay of Bengal & S Asia & 260 & $12(62)$ & 101 & 390 & $118(611)$ \\
\hline Godavari & Bay of Bengal & S Asia & 310 & $92(120)$ & 121 & 390 & $761(993)$ \\
\hline Mekong & South China Sea & SE Asia & 800 & 550 & 64 & 80 & 8594 \\
\hline Yellow & Yellow Sea & E Asia & 750 & $15(43)$ & 120 & 160 & $125(358)$ \\
\hline Yangtze & East China Sea & E Asia & 1800 & 900 & 475 & 264 & 1894 \\
\hline Pearl River & South China Sea & E Asia & 490 & 260 & 95 & 193 & 2749 \\
\hline Han River & Yellow Sea & E Asia & 25 & 17 & 13 & 513 & 1326 \\
\hline Asia total & & & $\begin{array}{r}32518 \\
(32518)\end{array}$ & $\begin{array}{r}11000 \\
(13196)\end{array}$ & 4835 & 148 & 227 \\
\hline Global total & & & $\begin{array}{r}105000 \\
(106326)\end{array}$ & $\begin{array}{r}36000 \\
(38170)\end{array}$ & 7345 & 70 & 4901 \\
\hline
\end{tabular}

River basin area and discharge data were obtained from Milliman and Farnsworth (2011), supplemented with Asian and global sums in parentheses from Ludwig et al. (1996). Pre-diversion discharge data are provided in parentheses for the rivers where discharge has substantially decreased in recent years because of river diversion, reservoir construction, and irrigation. The Asia total discharge provided by Milliman and Farnsworth (2011) was estimated for all rivers in Asia and Oceania, excluding Arctic rivers in Russia. Population data were taken from various sources including Schmidt et al. (2017) and the CIA World Factbook (https://www.cia.gov/library/publications/the-world-factbook/index.html; last accessed: 10 January 2018). Asia total population is the population for all countries belonging to Asia and Oceania excluding Russia.

tems (Grimm et al., 2008). As a consequence of global urbanization, human influences are pervasive across the interacting terrestrial and aquatic patches of riverine landscapes or riverscapes (Allan, 2004; McCluney et al., 2014). To emphasize the dominant human influences on connectivity and the interactions among terrestrial and aquatic patches of the riverine networks, we term these anthropogenically modified riverscapes "anthropogenic land-water-scapes". Compared to the previous use of the term "land-water-scape" focusing on terrestrial-aquatic boundary conditions in urbanized watersheds (Cadenasso et al., 2008), our use is more general and inclusive, covering longitudinal linkages between less or more modified upstream and downstream reaches. Rivers dominated by the effluents of wastewater treatment plants (WWTPs) provide an example of how human activities, through water withdrawal and wastewater generation, modify flows of water and materials across this anthropogenic land-water-scape. In the case of rivers draining arid areas, WWTP effluents can not only increase river flow but also provide a source of water feeding into habitats for various aquatic organisms along downstream reaches (Luthy et al., 2015). Rapid, concurrent changes in land use and river flow and chemistry make Asian rivers a perfect test bed for exploring how human-induced perturbations alter hydro-biogeochemical cycles across the components of these anthropogenic land-water-scapes.

New conceptual templates can build on some existing concepts that have been used to explain natural riverine processes. Above all, the river continuum from headwaters to mouth has been one of the most widely used concepts to represent longitudinal connectivity in river ecosystem structure and function over the last 5 decades (Vannote et al., 1980; Webster, 2007). The original river continuum concept envisaged gradual and continual changes in OM composition and metabolic rates in correspondence to downstream variations in environmental conditions and biotic communities along the river (Vannote et al., 1980; Fig. 2). Recent biogeochemical studies based on the river continuum concept include those of OM chemical diversity (Mosher et al., 2015) and biodegradability (Catalán et al., 2016) and riverine $\mathrm{CO}_{2}$ outgassing (Hotchkiss et al., 2015). A prevailing idea underlying these approaches has been the selective degradation of labile components of OM during transit across the continuum, which has been successful in explaining the critical role of water retention time for the downstream evolution of the composition and biodegradability of DOM in river systems with a relatively high proportion of natural lakes and/or low levels of anthropogenic perturbations (Koehler et al., 2012; Weyhenmeyer et al., 2012; Mosher et al., 2015; Catalán et al., 2016). According to the reactivity continuum model, the composition of DOM becomes dominated gradually by highly degraded compounds as a result of the prolonged exposure of DOM to biodegradation and photodegradation, resulting in a downstream decline in DOM reactivity (Koehler et al., 2012; Catalán et al., 2016).

Despite the wide use of the river continuum in studying various riverine processes, it has been criticized for overlooking an increasingly recognized reality that specific rivers 
are often divided into discrete segments that are hierarchically nested in a river network (Townsend, 1996; Poole, 2002). Discrete segments along a river network can occur as a result of "abrupt transitions between adjacent segments with dissimilar physical structure" within the hierarchically nested river network (Poole, 2002). These abrupt transitions between discrete segments can occur temporarily, as illustrated by seasonal variations in water connectivity (Casas-Ruiz et al., 2016). As depicted in Fig. 2, examples of human-induced discontinuities include those created by dams built on regulated rivers (Ward and Standford, 1983) and pollution-induced perturbations to the productionrespiration balance in the eutrophic river (Kempe, 1984; Garnier and Billen, 2007). Because the river continuum concept was originally proposed as a template for integrating physical environments and biological processes of "natural, unperturbed stream ecosystems" (Vannote et al., 1980), it has limitations in explaining discontinuities in fluvial processes and biogeochemical fluxes, which might be accentuated in many anthropogenically modified Asian river systems.

River impoundments and water withdrawal alter not only the rates of runoff and sediment transport (Syvitski et al., 2005) but also aquatic primary production and its effects on OM biodegradation (Stanley et al., 2012). In response to disturbance events, unregulated rivers tend to reset physical and ecological conditions toward the pre-disturbance state. However, river impoundment induces long-lasting perturbations to those conditions along the distance upstream or downstream of a dam, termed "discontinuity distance" (Ward and Standford, 1983; Stanford and Ward, 2001). This discontinuity distance was originally proposed as part of the "serial discontinuity concept", which states that stream regulation by multiple dams results in "an alternating series of lentic and lotic reaches" (Ward and Stanford, 1983). According to this concept, stream regulation by dams can induce disturbances to the gradual processes envisaged in the river continuum concept, shifting a given physical or biological parameter longitudinally (Ward and Stanford, 1983). For example, Vannote et al. (1980) envisaged that parameters such as the ratio of production to respiration $(P / R)$ and diel temperature difference $(\Delta T)$ would exhibit a specific longitudinal pattern shown in Fig. 2. Stream regulation can shift this longitudinal pattern along the discontinuity distance. Although the serial discontinuity concept has been a useful framework for assessing anthropogenic impacts on regulated lotic systems, its presuppositions, including no disturbances other than impoundment (Ward and Stanford, 1983), limit its application to investigating environmental stresses other than impoundments, such as the high levels of organic pollutants and nutrients observed in many Asian rivers receiving untreated sewage and urban runoff.

Kaushal and Belt (2012) proposed an urban watershed continuum framework that recognizes a continuum linking engineered and natural hydrologic flow paths across the urbanized watershed. From the perspective of spatial discon- nection within the hierarchically nested river network (Poole, 2002), this urban watershed continuum is actually "a continuum with discontinuities" (sensu Poole, 2002), in which the natural land-water hydrologic connectivity common in low-order streams is replaced by urban structures such as sewers and storm water drains. The lateral transfer of water and associated materials via networks of engineered urban structures not only creates departures from the natural patterns or "discontinuities" in the hydrologic paths across the terrestrial-aquatic interface, but also exerts extraordinary impacts on the downstream transport and transformations of OM and nutrients (Paul and Meyer, 2001; Allan, 2004; Garnier and Billen, 2007; Lookingbill et al., 2009; Kaushal and Belt, 2012). As Hynes (1975) emphasized the importance of the terrestrial-aquatic connectivity in headwater systems by saying that "the valley rules the stream", human-induced changes in the watershed would have large cascading effects on the structure and function of stream ecosystems. In human-modified river systems, the "valley" is often separated from the stream or replaced by engineered structures that release pulses of water and materials, creating abrupt transitions across the land-water interface and stream segments (Fig. 2). Urban structures across the land-water interface can also result in pulsatile flows of water and materials as a combined consequence of increased runoff from the impervious urban surface and discharges from WWTPs, storm water drainages, and combined sewer overflows (Paul and Meyer, 2001; Garnier and Billen, 2007; Kaushal and Belt, 2012). Although wastewater can bring pulses of OM and nutrients to the receiving urban water systems, its impact on riverine metabolism and $\mathrm{CO}_{2}$ outgassing has rarely been investigated in Asian river systems except for a few exploratory studies (Guo et al., 2014; Yoon et al., 2017).

Human-modified river networks often lack dynamic movements and flow adjustment and are therefore limited in their ability to buffer against disturbances such as floods and water stress (Palmer et al., 2008). Given the large seasonality inherent in the monsoon climate, anthropogenic land-waterscapes forming on monsoonal Asian river systems might be particularly vulnerable to climatic variability and extremes, as exemplified by the strengthened flashy storm responses of sediment and $\mathrm{C}$ export from erosion-prone mountainous watersheds during extremely wet monsoon periods (Park et al., 2010; Jung et al., 2012). Climate models have suggested that perturbations in the global water cycle accompanying climatic warming can increase river discharge in many parts of the world (Milly et al., 2005). Although increases in river discharge have been detected for some large basins over the last century (Labat et al., 2004), globally no consistent pattern has been established. For example, cumulative discharge from many midlatitude rivers, including rivers draining arid regions of Asia, have decreased substantially as a result of concurrent changes in precipitation and anthropogenic perturbations such as damming, irrigation, and inter-basin water transfers (Milliman et al., 2008). While discharge from most 


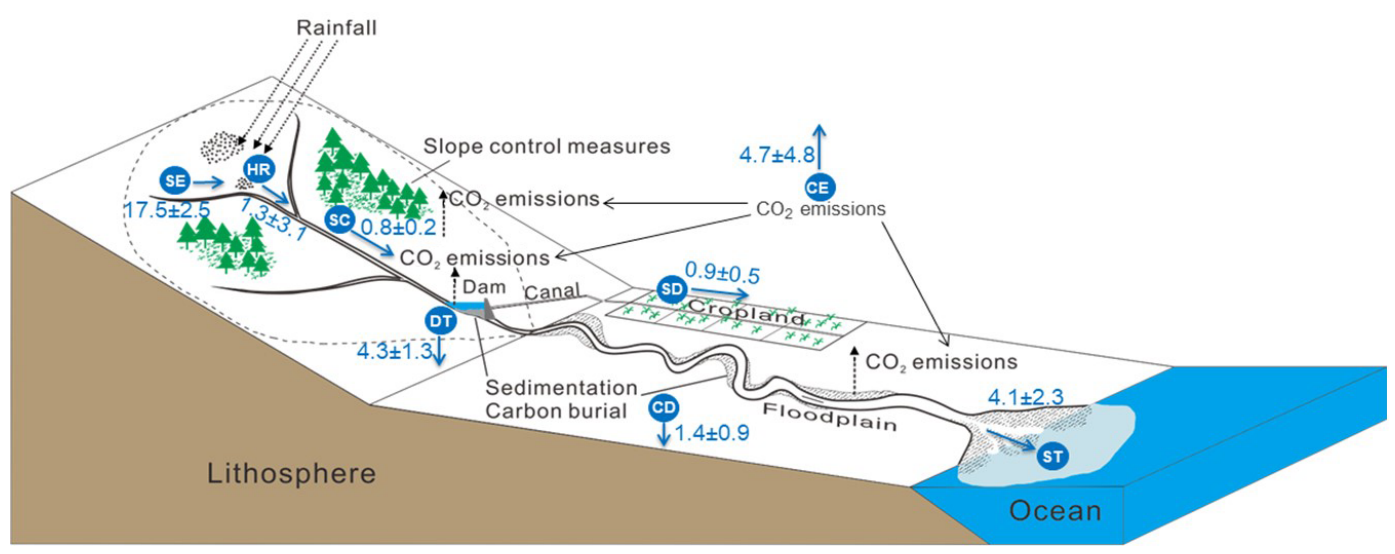

Figure 3. A schematic diagram illustrating human-induced alterations of the riverine $\mathrm{C}$ fluxes in the Yellow River as a model river system (modified from Ran et al., 2014). The annual flux rate $\left(\mathrm{Tg} \mathrm{C} \mathrm{yr}^{-1}\right)$ for each of the described soil and fluvial processes was estimated for the period 1950-2010. Slope and fluvial processes depicted in the figure include the following. SE: soil erosion, HR: hillslope redistribution, SC: slope control of erosion, DT: dam trapping, SD: sediment diversion, CD: channel deposition, $\mathrm{CE}$ : $\mathrm{CO}_{2}$ emission, and ST: seaward transport. Refer to Ran et al. (2014) for more details on their flux and uncertainty estimations.

Asian rivers except Siberian rivers and the Brahmaputra has declined, the most striking decrease exceeding $-50 \%$ was observed for the Indus and Yellow River (Milliman et al., 2008). In many dammed Asian rivers, observed decreases in discharge and sediment transport might be largely explained by increasing river impoundments and water diversion (Milliman et al., 2008; Li and Bush, 2015a). However, recent increases in the frequency and intensity of extreme precipitation events observed in many parts of Asia (Min et al., 2011) suggest that potential changes in monsoon rainfall regimes as a consequence of climate change can amplify seasonal and year-to-year variations in discharge and the transport of sediment and $\mathrm{C}$ even in dammed river systems. Therefore, predicting future changes in riverine $\mathrm{C}$ fluxes in increasingly human-modified Asian river systems would require a better understanding of the complex interplay between anthropogenic perturbations and the concurrent climate change.

\section{Contrasting effects of river impoundment on organic $\mathrm{C}$ transport and $\mathrm{CO}_{2}$ emission}

According to a recent estimate based on the Global Reservoir and Dam database (GRanD), there may be about 16.7 million reservoirs larger than 0.01 ha globally, with a combined storage capacity of $8069 \mathrm{~km}^{3}$ (Lehner et al., 2011). Out of 6862 dams registered in GRanD with a total storage capacity of $6197 \mathrm{~km}^{3}, 1906$ dams located in Asia (excluding middle eastern Asia and western Russia) store $1625 \mathrm{~km}^{3}$ of water, accounting for $26 \%$ of the global storage capacity. AQUASTAT, a global water information system operated by the Food and Agriculture Organization (FAO), provides a similar estimate for the reservoir storage capacity of southern and eastern Asia: $1325 \mathrm{~km}^{3}$ (Table 2; FAO, AQUASTAT). Over the last decades, rivers across Asia have been increas- ingly impounded by dams of various types and sizes, and a recent boom in constructing hydroelectric dams is posing an unprecedented challenge for the sustainable management of the affected river basins (Grumbine et al., 2012; Winemiller et al., 2016). River impoundments not only affect downstream flows but also disrupt the ecological and biogeochemical connectivity of rivers (Lehner et al., 2011; Winemiller et al., 2016; Maavara et al., 2017). A growing number of dams have been decreasing both river flow and sediment fluxes, sequestering over 100 billion metric tons of sediment and 1 to 3 billion metric tons of $\mathrm{C}$ in reservoirs constructed over the last 50 years (Syvitski et al., 2005). Many Asian rivers, such as the Indus, Yangtze, and Yellow, have seen the largest reductions in sediment export to the oceans compared to the pre-dam era (Syvitski et al., 2005). Therefore, investigating altered rates of $\mathrm{C}$ storage and losses in dammed Asian rivers is crucial for a better understanding of human impacts on global riverine $\mathrm{C}$ fluxes.

The Yellow River in northern China provides an excellent example of basin-scale impoundment impacts on sediment and $\mathrm{C}$ transport (Fig. 3). The sediment load in the Yellow River peaked during the period 1800-1950 following a millennium of aggravating soil erosion in the Loess Plateau, but dam construction and other human activities to control soil erosion have reduced the annual sediment flux by $90 \%$ over the last 60 years (Chen et al., 2015; Wang et al., 2015). Particularly, silt check dams and reservoirs, along with hillslope soil conservation measures such as terrace farming, made large contributions to the observed reductions. More than 110000 silt check dams have been constructed in the Loess Plateau since the 1950s, trapping approximately 21 billion tons of sediment in the reservoirs (Zhang et al., 2016). A conservative estimate indicates that the rate of annual POC trapping in more than 3000 large dams (exclud- 
Table 2. Summary of water use and wastewater production in southern and eastern Asia. Source of data: AQUASTAT, a global water information system operated by the Food and Agriculture Organization (FAO; http://www.fao.org/nr/water/aquastat/sets/index.stm; last access: 15 December 2017).

\begin{tabular}{|c|c|c|c|c|c|c|c|c|c|c|}
\hline \multirow[t]{3}{*}{ Country } & \multirow{3}{*}{$\begin{array}{l}\text { Population } \\
\qquad \begin{array}{r}(2015) \\
\times 10^{3}\end{array}\end{array}$} & \multirow{3}{*}{$\begin{array}{r}\begin{array}{r}\text { Renewable } \\
\text { surface water }\end{array} \\
(2014) \\
\mathrm{km}^{3} \mathrm{yr}^{-1}\end{array}$} & \multicolumn{2}{|c|}{ Dam capacity } & \multicolumn{2}{|c|}{ Municipal water } & \multicolumn{4}{|c|}{ Municipal wastewater } \\
\hline & & & \multirow[b]{2}{*}{$\mathrm{km}^{3}$} & \multirow[b]{2}{*}{ Year } & \multirow[b]{2}{*}{$\mathrm{km}^{3} \mathrm{yr}^{-1}$} & \multirow[b]{2}{*}{ Year } & \multicolumn{2}{|c|}{ Produced } & \multicolumn{2}{|c|}{ Treated } \\
\hline & & & & & & & $\mathrm{km}^{3} \mathrm{yr}^{-1}$ & Year & $\mathrm{km}^{3} \mathrm{yr}^{-1}$ & Year \\
\hline Bangladesh & 160996 & 1206.0 & 6.5 & 2013 & 3.6 & 2008 & 0.7 & 2000 & & \\
\hline Bhutan & 775 & 78.0 & & & 0.0 & 2008 & 0.0 & 2000 & & \\
\hline Brunei & 423 & 8.5 & 0.0 & 2010 & 0.2 & 2009 & & & & \\
\hline Cambodia & 15578 & 471.5 & & & 0.1 & 2006 & & & 0.0 & 1994 \\
\hline China & 1407306 & 2739.0 & 829.8 & 2013 & 75.0 & 2013 & 48.5 & 2013 & 49.3 & 2014 \\
\hline North Korea & 25155 & 76.2 & 13.6 & 2015 & 0.9 & 2005 & & & & \\
\hline India & 1311051 & 1869.0 & 224.0 & 2005 & 56.0 & 2010 & 15.5 & 2011 & 4.4 & 2011 \\
\hline Indonesia & 257564 & 1973.0 & 23.0 & 2015 & 14.0 & 2005 & 14.3 & 2012 & & \\
\hline Japan & 126573 & 420.0 & 29.0 & 1993 & 15.4 & 2009 & 16.9 & 2011 & 11.6 & 2011 \\
\hline Laos & 6802 & 333.5 & 7.8 & 2010 & 0.1 & 2003 & 0.1 & 2008 & 0.0 & 1995 \\
\hline Malaysia & 30331 & 566.0 & 22.5 & 2015 & 3.9 & 2005 & 4.2 & 2009 & 2.6 & 2009 \\
\hline Mongolia & 2959 & 32.7 & 0.3 & 2015 & 0.1 & 2009 & 0.1 & 2012 & 0.1 & 2006 \\
\hline Myanmar & 53897 & 1157.0 & 15.5 & 2005 & 3.3 & 2000 & & & 0.0 & 1995 \\
\hline Nepal & 28514 & 210.2 & 0.1 & 2015 & & & & & 0.0 & 2006 \\
\hline Pakistan & 188925 & 239.2 & 27.8 & 2015 & 9.7 & 2008 & 3.1 & 2011 & 0.0 & 2002 \\
\hline Papua New Guinea & 7619 & 801.0 & 0.7 & 2010 & 0.2 & 2005 & & & & \\
\hline Philippines & 100699 & 444.0 & 6.3 & 2006 & 6.2 & 2009 & 1.3 & 2011 & & \\
\hline South Korea & 50293 & 67.1 & 16.2 & 1994 & 6.9 & 2005 & 7.8 & 2011 & 6.6 & 2011 \\
\hline Singapore & 5619 & & 0.1 & 2015 & 1.1 & 2005 & 0.5 & 2013 & 0.5 & 2013 \\
\hline Sri Lanka & 20715 & 52.0 & 5.9 & 1996 & 0.8 & 2005 & 0.1 & 2009 & & \\
\hline Thailand & 67959 & 427.4 & 68.3 & 2010 & 2.7 & 2007 & 5.1 & 2012 & 1.2 & 2012 \\
\hline Timor & 1185 & 8.1 & & & 0.1 & 2004 & & & & \\
\hline Vietnam & 93448 & 847.7 & 28.0 & 2010 & 1.2 & 2005 & 2.0 & 2012 & 0.2 & 2012 \\
\hline $\mathrm{S}, \mathrm{SE}$, and E Asia & 3964386 & 14027.1 & 1325.2 & & 201.6 & & 120.2 & & 76.5 & \\
\hline World & 7344837 & 52952.7 & 7039.6 & & 464.1 & & 311.6 & & 187.1 & \\
\hline
\end{tabular}

ing 110000 silt check dams) within the Yellow River basin can amount to $3.3-4.3 \mathrm{Tg} \mathrm{C}^{-1}\left(1 \mathrm{Tg}=10^{12} \mathrm{~g}\right.$; Zhang et al., 2013; Ran et al., 2014), which is similar in magnitude to the total organic $\mathrm{C}$ export to the Bohai Sea $\left(4.1 \mathrm{Tg} \mathrm{Cyr}^{-1}\right.$; Ran et al., 2014; Fig. 3). Furthermore, as an important attempt to control soil erosion, the Chinese government initiated the largest ever revegetation program in history called the "Grain for Green Project" from the late 1990s. The implementation of this project has made an additional contribution to the decreasing trend of sediment flux (Wang et al., 2015), with far-reaching impacts on soil organic C stocks and riverine $\mathrm{C}$ fluxes (Feng et al., 2013). A great number of new silt check dams, up to 163000 , are planned to be built on the Loess Plateau through 2020 (Zhang et al., 2016), so dams and other erosion control projects will continue to have significant impacts on sediment and associated $\mathrm{C}$ dynamics in the Yellow River basin in the future.

It remains an important research question whether POC trapped in ever-growing reservoir sediments within the Yellow River basin would function as a sink or source of $\mathrm{CO}_{2}$ for the atmosphere (Zhang et al., 2013; Ran et al., 2015a, 2017a).
As illustrated by the relatively high estimated rate $(27 \%)$ of $\mathrm{CO}_{2}$ emission from the POC eroded from the entire Yellow River basin (Ran et al., 2014; Fig. 3), the organic C trapped in reservoir and stream sediments can become an important source of $\mathrm{CO}_{2}$ under favorable conditions that would accelerate the rate of the biodegradation of POC during fluvial transport and sediment storage. Although the rate of $\mathrm{CO}_{2}$ evasion from the water surface can increase in the impounded river reaches, as longer residence times tend to create favorable environments for the microbial biodegradation of organic $\mathrm{C}$ (Ittekkot et al., 1985; Ran et al., 2015a), the countering effect of enhanced planktonic $\mathrm{CO}_{2}$ uptake in the euphotic reservoir surface has rarely been compared against biodegradation (refer to the wide range of $p \mathrm{CO}_{2}$ summarized in Table 3). Based on extensive $\mathrm{CO}_{2}$ evasion measurements in the river-reservoir-river continuum on the Loess Plateau, Ran et al. (2017a) found that the Loess Plateau reservoirs acted as relatively small sources or even sinks of $\mathrm{C}$ due largely to significantly reduced surface turbulence and enhanced photosynthesis. Compared to the standing waters of the reservoirs with enhanced primary production, rapidly flowing wa- 
Table 3. Summary of $p \mathrm{CO}_{2}$ measured (M) or estimated (E) for the rivers in South (S), Southeast (SE), and East (E) Asia in comparison with data for the global rivers including Asian rivers. Only a single value per site was used to obtain the mean and range of each Asian river system, so multiple measurements at a site were averaged to provide one representative value.

\begin{tabular}{|c|c|c|c|c|c|c|c|}
\hline \multirow[t]{2}{*}{ River system } & \multicolumn{5}{|c|}{ Mean (range) of $p \mathrm{CO}_{2}(\mu \mathrm{atm})$} & \multirow[t]{2}{*}{ Method } & \multirow[t]{2}{*}{ Reference } \\
\hline & Basin wide & Main stem & Headwater & Tributary & Impoundment & & \\
\hline \multirow[t]{3}{*}{ Global } & $\begin{array}{r}3100 \\
(0-100000)\end{array}$ & & & & & $\mathrm{E}$ & $\begin{array}{l}\text { Raymond et al. (2013), } \\
\text { GLORCIH }^{\mathrm{a}}\end{array}$ \\
\hline & $\begin{array}{r}2400 \\
(2019-2826)\end{array}$ & & & & & $\mathrm{E}$ & $\begin{array}{l}\text { Lauerwald et al. (2015), } \\
\text { GLORICH }^{\mathrm{a}}\end{array}$ \\
\hline & & & $\begin{array}{r}4196^{\mathrm{b}} \\
(32-93616)\end{array}$ & & & $\mathrm{E} / \mathrm{M}$ & $\begin{array}{l}\text { Marx et al. (2017), } \\
\text { GLORICH }^{\mathrm{a}}\end{array}$ \\
\hline Asia (total) & $\begin{array}{r}1754 \\
(28-11793)\end{array}$ & $\begin{array}{r}1263 \\
(35-10977)\end{array}$ & $\begin{array}{r}1170 \\
(74-5076)\end{array}$ & $\begin{array}{r}2116 \\
(28-11793)\end{array}$ & $\begin{array}{r}835 \\
(128-8785)\end{array}$ & & $\begin{array}{l}\text { Sum of freshwater } \\
\text { data below }\end{array}$ \\
\hline \multicolumn{8}{|l|}{ S Asia } \\
\hline Ganges & $\begin{array}{r}893 \\
(65-2620)\end{array}$ & $\begin{array}{r}1083 \\
(65-2184)\end{array}$ & $\begin{array}{r}401 \\
(165-1222)\end{array}$ & $\begin{array}{r}1685 \\
(1035-2620)\end{array}$ & $181,224^{\mathrm{c}}$ & $\mathrm{E} / \mathrm{M}$ & $\begin{array}{l}\text { Manaka et al. (2015b), } \\
\text { GLORICH }^{\mathrm{a}}\end{array}$ \\
\hline Brahmaputra & $\begin{array}{r}664 \\
(28-6706)\end{array}$ & $\begin{array}{r}494 \\
(65-6706)\end{array}$ & $\begin{array}{r}292 \\
(208-513)\end{array}$ & $\begin{array}{r}758 \\
(28-3678)\end{array}$ & & $\mathrm{E}$ & $\begin{array}{l}\text { Huang et al. (2011), Manaka et al. (2015b), } \\
\text { Qu et al. (2017), GLORICH }{ }^{\mathrm{a}}\end{array}$ \\
\hline Indus & $\begin{array}{r}853 \\
(117-7725)\end{array}$ & $\begin{array}{r}941 \\
(117-7725)\end{array}$ & & $\begin{array}{r}768 \\
(165-3161)\end{array}$ & & $\mathrm{E}$ & GLORICH $^{\mathrm{a}}$ \\
\hline Krishna & $\begin{array}{r}2152 \\
(711-4098)\end{array}$ & $\begin{array}{r}1871 \\
(976-2536)\end{array}$ & & $\begin{array}{r}2305 \\
(711-4098)\end{array}$ & & $\mathrm{E}$ & GLORICH $^{\mathrm{a}}$ \\
\hline Godavari & $8785^{\mathrm{d}}$ & & & & $8785^{\mathrm{d}}$ & $\mathrm{E}$ & Prasad et al. (2013) \\
\hline Bhote Kosi & $\begin{array}{r}592 \\
(35-5907)\end{array}$ & $\begin{array}{r}592 \\
(35-5907)\end{array}$ & & & & $\mathrm{E}$ & GLORICH $^{\mathrm{a}}$ \\
\hline Various & $\begin{array}{r}2685 \\
(420-10977)\end{array}$ & $\begin{array}{r}3081 \\
(426-10977)\end{array}$ & & & $\begin{array}{r}609 \\
(420-692)\end{array}$ & $\mathrm{E} / \mathrm{M}$ & Panneer Selvam et al. (2014) \\
\hline Cochin & $(2975-6001)^{\mathrm{e}}$ & & & & & E & Gupta et al. (2009) (saline estuary) \\
\hline Other estuaries & $5882(293-18492)$ & & & & & E & Sarma et al. (2012) (saline estuary) \\
\hline \multicolumn{8}{|l|}{ SE Asia } \\
\hline Mekong & $\begin{array}{r}1235 \\
(110-4503)\end{array}$ & $\begin{array}{r}1120 \\
(703-1687)\end{array}$ & $1367^{\mathrm{f}}$ & $\begin{array}{r}1310 \\
(110-4503)\end{array}$ & $\begin{array}{r}882^{\mathrm{g}} \\
(864-899)\end{array}$ & $\mathrm{E} / \mathrm{M}$ & $\begin{array}{l}\text { Alin et al. (2011), Li et al. (2013b), } \\
\text { Manaka et al. (2015a) }\end{array}$ \\
\hline Red River & $\begin{array}{r}1589 \\
(992-3129)\end{array}$ & $\begin{array}{r}1589 \\
(992-3129)\end{array}$ & & & & M & Le et al. (2017) \\
\hline Irrawaddy & $\begin{array}{r}2007 \\
(1222-3157)\end{array}$ & $\begin{array}{r}2007 \\
(1222-3157)\end{array}$ & & & & $\mathrm{E}$ & Manaka et al. (2015a) \\
\hline Chao Phraya & $\begin{array}{r}3202 \\
(925-5076)\end{array}$ & $\begin{array}{r}2814 \\
(2632-2996)\end{array}$ & $\begin{array}{r}3357 \\
(925-5076)\end{array}$ & & & $\mathrm{E}$ & Manaka et al. (2015a) \\
\hline Malaysian rivers & $\begin{array}{r}1217 \\
(1159-1274)\end{array}$ & $\begin{array}{r}1217 \\
(1159-1274)\end{array}$ & & & & M & Wit et al. (2015) \\
\hline Indonesian rivers & $\begin{array}{r}5262 \\
(2400-8555)\end{array}$ & $\begin{array}{r}5262 \\
(2400-8555)\end{array}$ & & & & M & Wit et al. (2015) \\
\hline \multicolumn{8}{|l|}{ E Asia } \\
\hline Yellow & $\begin{array}{r}2164 \\
(147-9659)\end{array}$ & $\begin{array}{r}2104 \\
(582-4770)\end{array}$ & $\begin{array}{r}1083 \\
(147-3546)\end{array}$ & $\begin{array}{r}2470 \\
(425-9659)\end{array}$ & $\begin{array}{l}555,441^{\mathrm{h}} \\
(266-735)\end{array}$ & $\mathrm{E} / \mathrm{M}$ & $\begin{array}{l}\text { Ran et al. (2015a), } \\
\text { Ran et al. (2017a) }\end{array}$ \\
\hline Yangtze & $\begin{array}{r}2366 \\
(74-7718)\end{array}$ & $\begin{array}{r}1322 \\
(528-3800)\end{array}$ & $\begin{array}{r}794 \\
(74-4472)\end{array}$ & $\begin{array}{r}2680 \\
(249-7718)\end{array}$ & $\begin{array}{r}1393 \\
(760-1908)\end{array}$ & E & $\begin{array}{l}\text { Qu et al. (2015), Liu et al. (2016), } \\
\text { Ran et al. }\left(2017 b^{\mathrm{i}}\right) \text {, GLORICH } \\
\text { a }\end{array}$ \\
\hline Pearl River & $\begin{array}{r}1747 \\
(231-5006)\end{array}$ & $\begin{array}{r}2465 \\
(2136-2833)\end{array}$ & $\begin{array}{r}1671 \\
(231-5006)\end{array}$ & $\begin{array}{r}1967 \\
(282-4808)\end{array}$ & & $\mathrm{E}$ & $\begin{array}{l}\text { Yao et al. (2007), Zhang et al. (2009), } \\
\text { Zou (2016), GLORICH }\end{array}$ \\
\hline Han River & $\begin{array}{r}2571 \\
(101-11793)\end{array}$ & $\begin{array}{r}1480 \\
(173-4089)\end{array}$ & 628 & $\begin{array}{r}4670 \\
(101-11793)\end{array}$ & $\begin{array}{r}251 \\
(128-454)\end{array}$ & M & Yoon et al. (2017) \\
\hline
\end{tabular}

${ }^{a}$ GLORICH: Global River Chemistry Database (Hartmann et al., 2014), from which $p \mathrm{CO}_{2}$ for global rivers was calculated by Raymond et al. (2013; excluding data obtained at pH <5.4) and Lauerwald et al. (2015) excluding data obtained high pollution levels. Marx et al. (2017) excluded $p \mathrm{CO}_{2}$ values above $100000 \mu$ atm to avoid any potential overestimation resulting from pH and alkalinity effects. ${ }^{\mathrm{b}}$ The mean and range were calculated from the data set (GLORICH and additional literature data) of $p \mathrm{CO}_{2}$ measured or estimated for streams draining small watersheds $<20 \mathrm{~km}{ }^{2}$ (Marx et al., 2017 ). ${ }^{\mathrm{C}}$ Dakpatthar Barrage on the Yamuna, a Ganges tributary (cf. the other barrage at Rishikesh on the main stem), using the headspace equilibration method (Park, unpublished data). ${ }^{\mathrm{d}}$ Dowleiswaram Reservoir (only the mean of time series data was included in calculating the regional mean and range) ${ }^{\mathrm{e}}$ Cochin estuary: 2 sites on the Periyar River and 11 sites on the estuary. ${ }^{f}$ Measured at Lancang headwater at Qinghai, China using the headspace equilibration method (Park, unpublished data). ${ }^{\mathrm{g}}$ Impounded tributaries of the lower Mekong (Li et al., 2013b). ${ }^{\mathrm{h}}$ Impoundments on a Yellow River tributary (Ran et al., 2017a). ${ }^{\mathrm{i}}$ Ran et al. (2017b) excluded $p \mathrm{CO}{ }_{2}$ values calculated at $\mathrm{pH}<6.5$. 
ters along both the upstream and downstream reaches were larger $\mathrm{C}$ sources for the atmosphere, exhibiting much higher $p \mathrm{CO}_{2}$ levels and faster flow velocities, which provide favorable conditions for an efficient gas evasion from the aqueous boundary layer. Liu et al. (2016) also observed over $60 \%$ decreases in $p \mathrm{CO}_{2}$ along the eutrophic impounded reaches of the Three Gorge Reservoir in the Yangtze River, but they argued that enhanced primary production in the impounded reach would play a rather temporary and minor role in controlling $p \mathrm{CO}_{2}$ dynamics compared to the predominant influence of allochthonous $\mathrm{C}$. The contrasting impoundment effects observed in the Yellow River and other Chinese rivers suggest that a basin-wide assessment of impoundment impacts on sediment $\mathrm{C}$ storage and $\mathrm{CO}_{2}$ emissions should take into consideration concurrent changes in primary production and organic matter biodegradation.

In the Lancang River (the upper Mekong River located in China), Li et al. (2013a) observed dramatic increases in the abundance of phytoplankton and a shift of the algal community toward Chlorophyta and Cyanophyceae following the construction of cascade dams since 1995 . In a recent study that compared the emission rates of $\mathrm{CO}_{2}$ and $\mathrm{CH}_{4}$ across the upper riverine reach and six cascade dams along the Lancang River, Shi et al. (2017) found that gas emission rates, particularly those of $\mathrm{CH}_{4}$, were highest in the most upstream and second newest dam and that the percent of organic $\mathrm{C}$ in the reservoir bottom sediment had decreased with the increasing age of the dams. These results suggest that favorable conditions created by river impoundments, such as increased water temperature and retention time, can stimulate OM processing in both the impounded water and trapped sediments, at least in the short term following the construction of dams on highPOC mountainous rivers such as the Lancang.

Most major Indian rivers have been impounded by dams of various types and sizes to meet domestic and industrial water demands during the dry period. Because monsoonal rivers draining the Indian subcontinent account for the largest share of the POC export by the Asian rivers (Ludwig et al., 1996; Galy et al., 2015), altered discharges and sediment fluxes of these dammed rivers can have significant implications for the global riverine export of sediment and POC (Ittekkot et al., 1985; Krishna et al., 2015). However, the effects of large dams on riverine $\mathrm{C}$ fluxes including $\mathrm{CO}_{2}$ have been studied only in a few dammed rivers such as the Godavari (Sarma et al., 2011; Prasad et al., 2013; Table 3). According to an earlier study conducted in the Krishna, dam construction had decreased the sediment load from $67.7 \mathrm{Tg} \mathrm{yr}^{-1}$ measured at the upper reach to $4.11 \mathrm{Tg} \mathrm{yr}^{-1}$ at the river mouth (Ramesh and Subramanian, 1988). Although many large dams and barrages have been constructed on the main stem and tributaries of the Ganges, there has been no systematic investigation of GHG emissions from the impounded reaches, except for a few unpublished measurements (Table 3). Because of this paucity of monitoring data, GHG emissions from impounded rivers add a considerable uncertainty to the estimates of GHG emissions from the inland water systems in the Indian subcontinent. For instance, Panneer Selvam et al. (2014) extrapolated their flux measurements at 45 water bodies in South India to estimate $\mathrm{CO}_{2}$ and $\mathrm{CH}_{4}$ emissions from all of India's inland waters at $22.0 \mathrm{Tg} \mathrm{CO}$ and $2.1 \mathrm{Tg} \mathrm{CH}_{4} \mathrm{yr}^{-1}$, respectively. While they provided estimates of $2.37 \mathrm{Tg} \mathrm{CO}_{2}$ and $0.33 \mathrm{Tg} \mathrm{CH}_{4} \mathrm{yr}^{-1}$ for the reservoirs and barrages, a follow-up study offered larger estimates amounting to $3.08 \mathrm{Tg} \mathrm{CO}_{2}$ and 6.27 $\mathrm{Tg} \mathrm{CH}_{4} \mathrm{yr}^{-1}$ by considering additional literature data on large rivers in northern India and reservoir downstream fluxes through spillways and turbines ( $\mathrm{Li}$ and Bush, 2015b). This example illustrates the importance of adequate spatial coverage and downstream impacts for refining regional-level estimates of GHG emissions from various impoundments.

A significant reduction in primary production observed in the Godavari River was ascribed to the removal of nitrogen and phosphorus by several dams constructed within the basin (Das, 2000). Ramesh et al. (2015) reported an increasing retention of particulate $\mathrm{OM}$ in the dams and reservoirs of the Godavari and Krishna. However, other studies conducted in the Godavari estuary have found that during the peak discharge periods in the monsoon season, the estuary receiving discharge waters from an upstream dam exhibited extraordinarily high levels of $p \mathrm{CO}_{2}$ up to $33000 \mu$ atm compared to the dry season values lower than $500 \mu$ atm, presumably due to enhanced bacterial decomposition of the organic $\mathrm{C}$ released from the upstream dam in the highly eutrophic estuary (Sarma et al., 2011; Prasad et al., 2013). On the other hand, less rainfall during dry years can also result in large downstream impacts of impoundments through an increased production of labile OM by freshwater algae in the upstream dam and algal blooms in the estuary (Pradhan et al., 2014). Further research is required to establish how seasonal and interannual variations in climatic and trophic conditions in dammed Indian rivers alter the balance between autotrophy and heterotrophy and hence $\mathrm{CO}_{2}$ emissions along the "discontinuous" river-reservoir-estuary continuum as found in the Godavari basin.

In accordance with the serial discontinuity concept (Ward and Standford, 1983; Fig. 2), multiple dams constructed on large Asian rivers such as the Mekong and Yellow River create standing water conditions that may shift stream metabolisms and $p \mathrm{CO}_{2}$ dynamics from the patterns observed for freely flowing reaches. The observed contrasting impoundment effects on $\mathrm{CO}_{2}$ emissions across different Asian river systems might have resulted from an interplay between planktonic $\mathrm{CO}_{2}$ uptake, organic matter biodegradation, and sediment $\mathrm{C}$ sequestration (Liu et al., 2016; Maavara et al., 2017). The balance between the competing processes affecting the actual level of $p \mathrm{CO}_{2}$ in reservoir waters may change not only seasonally (Prasad et al., 2013; Liu et al., 2016) but also with the increasing age of dams (Barros et al., 2011). While large pulses of GHGs may be released from the flooded vegetation and soil OM during the initial flooding phase (Abril et al., 2005; Chen et al., 2009; Hu and Cheng, 


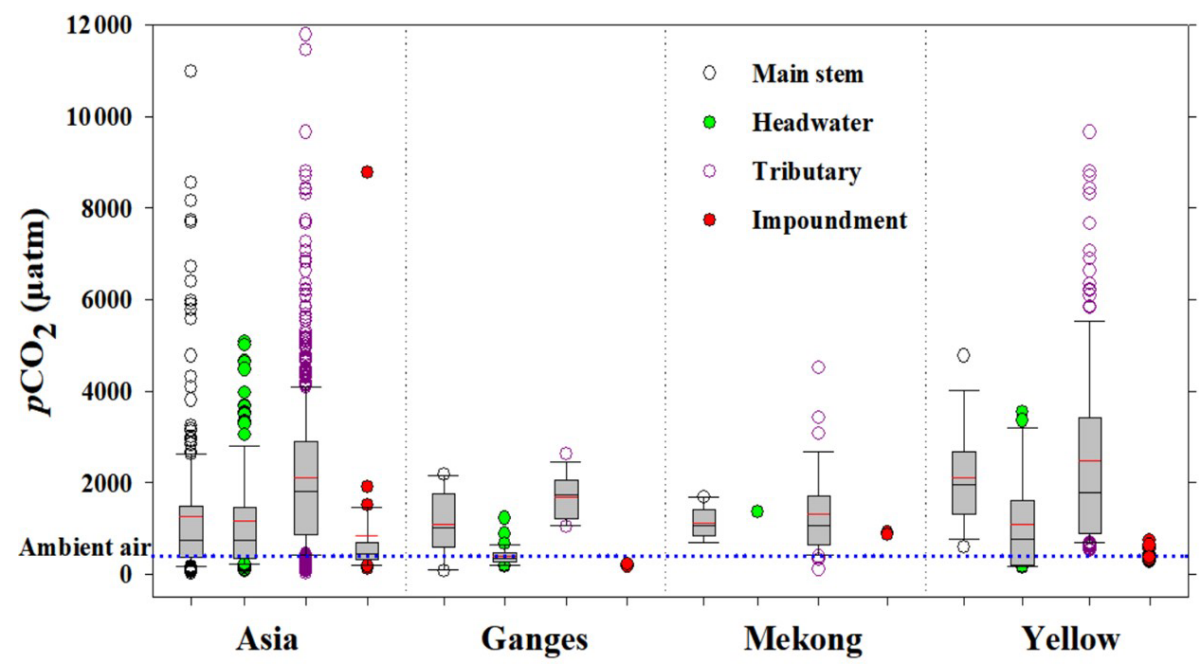

Figure 4. Comparison of $p \mathrm{CO}_{2}$ measured or estimated for major Asian rivers, including three rivers selected for a detailed review - the Ganges, Mekong, and Yellow River. The blue dotted line indicates the ambient air $p \mathrm{CO}_{2}$ level around 400 atm. The horizontal black and red lines of the box plots are the median and mean value, respectively. Each box covers the 25th to 75th percentile, whereas the whiskers represent the 10th and 90th percentile. The number of data points included in the total Asian rivers is 1240 (main stem: 261, headwater: 199 , tributary: 750, impoundment: 30), in the Ganges 63 (main stem: 14, headwater: 30, tributary: 17, impoundment: 2), in the Mekong 59 (main stem: 19, headwater: 1, tributary: 37, impounded tributary: 2), and in the Yellow River 215 (main stem: 14, headwater: 22, tributary: 164, impoundment: 15). Refer to Table 3 for more details on data sources.

2013; Deshmukh et al., 2016, 2018), sedimentation can accumulate a growing amount of $\mathrm{C}$ in reservoir sediments, greatly decreasing the rate of $\mathrm{CO}_{2}$ release from aging reservoirs (Barros et al., 2011). Large pulse emissions of $\mathrm{CO}_{2}$ and $\mathrm{CH}_{4}$ have been measured in the years following the construction of the Three Gorges Dam on the Yangtze River (Chen et al., 2009) and the Nam Theun 2 on the large tributary feeding into the middle reach of the Mekong River (Deshmukh et al., 2016, 2018). A recent report on drought-enhanced emissions of GHGs in an old hydroelectric reservoir in Korea suggested that stochastic emissions during extreme climatic events can reverse the trend of declining $\mathrm{C}$ emissions from aging reservoirs through the offsetting effect of extreme events on the $\mathrm{C}$ accumulated in reservoir sediments over timescales of years to decades (Jin et al., 2016). The paucity of $p \mathrm{CO}_{2}$ measurements in dammed Asian rivers (Table 3; Fig. 4) does not allow for any generalization of long-term impoundment effects on sediment $\mathrm{C}$ storage and $\mathrm{CO}_{2}$ emissions; this requires more long-term investigations of seasonal and year-to-year variations in metabolic processes and $p \mathrm{CO}_{2}$ levels across a wide range of impounded inland water systems.

\section{Effects of water pollution on riverine metabolisms and $\mathrm{CO}_{2}$ emissions}

Across Asia, rapidly urbanizing river basins are highly polluted with poorly treated or untreated wastewater. Using AQUASTAT data, Evans et al. (2012) estimated the annual wastewater generation in Asia around the year 2000 at
$142 \mathrm{~km}^{3}$, of which only an estimated $33-35 \%$ was treated before being discharged to streams and rivers. We used the latest data available on the AQUASTAT webpage to provide more up-to-date estimates of water withdrawal and wastewater production, focusing on southern and eastern Asia (FAO, AQUASTAT). In 2010, the annual municipal water withdrawal in 24 southern and eastern Asian countries was $201.6 \mathrm{~km}^{3}$, accounting for $43.4 \%$ of the global municipal withdrawal $\left(464.1 \mathrm{~km}^{3}\right.$; Table 2$)$. The total volume of municipal wastewater generated each year within urban areas of these countries was $120.2 \mathrm{~km}^{3}$. The generated wastewater included domestic, commercial, and industrial effluents and storm water runoff, accounting for $38.6 \%$ of the global municipal wastewater production $\left(311.6 \mathrm{~km}^{3}\right)$. Based on the AQUASTAT and other published data, MateoSagasta et al. (2015) estimated that each year more than $330 \mathrm{~km}^{3}$ of municipal wastewater is produced globally. Although the volume of municipal wastewater generated constitutes only $\sim 0.9 \%$ of the renewable surface water available in these Asian regions $\left(14027.1 \mathrm{~km}^{3}\right)$, both poorly treated and untreated wastewater can have disproportionately large impacts not only on the water quality and ecological integrity of downstream aquatic ecosystems (Meybeck and Helmer, 1989; Evans et al., 2012) but also on the riverine GHG emissions (Yoon et al., 2017).

Compared to extensive studies conducted in polluted rivers and estuaries in Europe and North America (Frankignoulle et al., 1998; Borges et al., 2006; Hartmann et al., 2007; Borges and Abril, 2011; Griffith and Raymond, 2011; Amann et al., 2012; Joesoef et al., 2015), few efforts have been made to 
measure $\mathrm{pCO}_{2}$ in polluted Asian rivers, except for some large rivers and estuaries in East Asia (Zhai et al., 2005; Chou et al., 2013; Ran et al., 2015b; Yoon et al., 2017). These studies, together with a small number of studies that used water chemistry data to estimate $p \mathrm{CO}_{2}$ levels in major Asian rivers such as the Mekong ( $\mathrm{Li}$ et al., 2013b), the Yangtze (Ran et al., 2017b), the Ganges-Brahmaputra (Manaka et al., 2015b), and Indian estuaries (Gupta et al., 2009; Sarma et al., 2012), underscored the importance of anthropogenic $\mathrm{OM}$ and nutrients for riverine $\mathrm{CO}_{2}$ dynamics, particularly along lower river reaches and estuaries draining highly populated areas. When published data on $p \mathrm{CO}_{2}$ were compared between headwater streams and tributaries feeding into the middle and lower reaches of major Asian rivers, tributary $p \mathrm{CO}_{2}$ levels (mean: $2116 \mu \mathrm{atm}$ ) tended be higher than those for headwaters of Asian rivers (mean: $1170 \mu \mathrm{atm}$; Table 3; Fig. 4). The ranges of $p \mathrm{CO}_{2}$ in the three river systems reviewed in detail also differed between headwaters and lower main stem reaches and their tributaries, displaying some river-specific patterns as described in the following paragraphs.

With the basin-wide average $p \mathrm{CO}_{2}$ around 2164 (1479659) $\mu$ atm (Table 3), the Yellow River has been evaluated as a source of $\mathrm{CO}_{2}$ for the atmosphere (Ran et al., 2015a, b, 2017a; Fig. 3). The total emission of $\mathrm{CO}_{2}$ from the basin-wide fluvial network was estimated at $4.7-7.9 \mathrm{Tg} \mathrm{yr}^{-1}$, with $>70 \%$ emitting from the tributaries draining the Loess Plateau (Ran et al., 2014, 2015b; Fig. 3). In recent decades water pollution has become an increasingly important watershed management issue for the basin inhabited by a population $>100$ million, particularly in the middle and lower reaches flanked by large industrial complexes and irrigated farmlands (Li et al., 2006; Zhang et al., 2013; Lu et al., 2015). Drainage waters from croplands containing high loads of OM have increased DOC concentrations in the middle reach of the Yellow River, while wastewater discharged from large regional population centers has been evaluated as the major source of DOC and POC in the lower reach, particularly in winter (Zhang et al., 2013). As a combined result of higher loads of pollutants discharged from local sources to tributaries and higher flow diluting pollutant concentrations in the main stem, tributaries appear to be more polluted than the main stem Yellow River, exhibiting the highest levels of $p \mathrm{CO}_{2}$ among the three compared river systems (Fig. 4). Higher concentrations of DOC and POC in more polluted lower reaches and their tributaries might lead to enhanced instream biodegradation of allochthonous $\mathrm{C}$ by labile $\mathrm{OM}$ fractions of anthropogenic origin, but altered rates of biodegradation and primary production have not yet been measured in any reach of the Yellow River. Along with the question about impoundment effects on sediment $\mathrm{C}$, the role of organic pollution in riverine metabolisms and $\mathrm{CO}_{2}$ emissions along lower reaches is crucial for understanding the fate of organic C derived from various sources in the Yellow River basin, including $\mathrm{C}$ stocks stored in reservoir and floodplain sediments.

It is very difficult to evaluate the overall pollution impacts on $\mathrm{C}$ dynamics of the main stem Mekong River, as measurements of the nutrient and $\mathrm{C}$ cycles have been made for short reaches of the lower Mekong in Laos and Cambodia (Alin et al., 2011; Ellis et al., 2012; Martin et al., 2013) and in the Mekong Delta (Borges et al., 2018). The annual DIC flux of the Mekong was estimated at 3.95 Tg, with DIC and alkalinity both negatively correlated with discharge (Jeffrey E. Richey, unpublished data). This trend, which has also been observed in the Pearl (Zhang et al., 2007) and Yellow River (Ran et al., 2015a), has been attributed to the dominance of a weathering-based source in the dry season that is diluted by less ion-rich rainwater during the high-flow periods (Cai et al., 2008). The mean reported $p \mathrm{CO}_{2}$ value for the lower Mekong River is $1235 \mu \mathrm{atm}$ (Table 3). Using a model based on $\mathrm{pH}$ and alkalinity, Li et al. (2013b) reported a similar mean $p \mathrm{CO}_{2}$ for the lower Mekong: 1090 (224-5970) $\mu \mathrm{atm}$. Alin et al. (2011) measured similar values $(\sim 1200 \mu$ atm $)$ at eight main stem locations in Laos and Cambodia. The seasonal trend in $p \mathrm{CO}_{2}$ opposes the alkalinity and DIC trends, peaking in the flood season and being lowest in the dry season, similar to several previous studies in tropical river systems (Sarma et al., 2011; Borges et al., 2018). The level of $p \mathrm{CO}_{2}$ in the lower Mekong tends to increase downstream, with an average of $812 \mu$ atm near Chiang Saen, Thailand increasing toward $1670 \mu \mathrm{atm}$ in the Mekong Delta (Li et al., 2013b). The potential effects of polluted tributaries on main stem $\mathrm{CO}_{2}$ emissions were indicated by high $p \mathrm{CO}_{2}$ values approaching $2000-3000 \mu$ atm in tributaries draining highly populated areas such as the Tonle Sap near Phnom Penh and local tributaries feeding into the Mekong Delta (Li et al., 2013b; Table 3). In Phnom Penh, a combined drainage system delivers untreated municipal wastewater and storm runoff either directly or through four natural wetlands surrounding the city used for natural purification to the Tonle Sap and Mekong (Irvine et al., 2006). Measurements of $p \mathrm{CO}_{2}$ along three freshwater channels in the Mekong Delta ranged between 1895 and $2664 \mu$ atm during the high-flow periods of December 2003 and October 2004 (Borges et al., 2018) and exceeded the range of 703$1597 \mu \mathrm{atm}$ observed in the upstream reach during a similar period (September-October 2004 and 2005) by Alin et al. (2011). As suggested by Borges et al. (2018), anthropogenic pollution sources in the densely populated and cultivated areas along lower reaches may release more $\mathrm{CO}_{2}$ and biodegradable OM compared to the upstream reach.

As summarized in Table 3, many studies of aquatic $\mathrm{CO}_{2}$ dynamics in India have been conducted in estuaries and coastal areas (Mukhopadhyay et al., 2002; Biswas et al., 2004; Gupta et al., 2009; Sarma et al., 2012; Samanta et al., 2015), except for the secondary data on $p \mathrm{CO}_{2}$ calculated using $\mathrm{C}$ system equations (Pierrot et al., 2006) and water quality data collected in various headwaters (Sarin et al., 1989; 
Bickle et al., 2003; Chakrapani and Veizer, 2005) and lower reaches (Manaka et al., 2015b) of the Ganges-Brahmaputra. The values of $p \mathrm{CO}_{2}$ estimated for some headwaters, lower reaches, and tributaries of the Ganges basin (mean: 893; range: $65-2620 \mu \mathrm{atm})$ were relatively low compared to other Asian rivers (Table 3; Fig. 4). In a study of the human impacts on $\mathrm{C}$ dynamics in the Cochin estuary in southern India, Gupta et al. (2009) ascribed monsoonal $p \mathrm{CO}_{2}$ increases of up to $6000 \mu \mathrm{atm}$ to the enhanced decomposition of the $\mathrm{OM}$ released from anthropogenic sources upstream. Particular attention has been paid to the emission of $\mathrm{CO}_{2}$ and $\mathrm{CH}_{4}$ from the Indian part of the deltaic region of the GangesBrahmaputra system that includes estuaries with contrasting biogeochemical features: the anthropogenically impacted estuary of the Hooghly (the largest Indian distributary of the Ganges emptying into the Bay of Bengal) and the mangrovedominated estuaries of Sundarbans, the world's largest mangrove ecosystem (Mukhopadhyay et al., 2002; Biswas et al., 2004; Dutta et al., 2015; Samanta et al., 2015). The Hooghly estuary was found as net heterotrophic, with the fugacity of $\mathrm{CO}_{2}\left(f \mathrm{CO}_{2}\right)$ varying from $\sim 400$ to $700 \mu$ atm (Mukhopadhyay et al., 2002). On an annual scale, the Hooghly estuary acted as a source of $\mathrm{CO}_{2}\left(-2.78\right.$ to $\left.84.4 \mathrm{mmol} \mathrm{m}^{-2} \mathrm{~d}^{-1}\right)$ to the atmosphere (Mukhopadhyay et al., 2002). The estuaries of Sundarbans were reported as a source of $\mathrm{CO}_{2}$ (314.6 $\mathrm{mmol} \mathrm{m}^{-2} \mathrm{~d}^{-1}$ ) to the atmosphere (Dutta et al., 2015). Samanta et al. (2015) reported a large annual DIC export of $(3.1-3.7) \times 10^{12} \mathrm{~g}$ from the Hooghly estuary to the Bay of Bengal exceeding the input of DIC through the river (freshwater). They attributed the estuarine production of DIC to some biogeochemical processes within the estuary including OM biodegradation and carbonate dissolution. Drawing on wastewater discharge and DIC concentrations, Samanta et al. (2015) estimated that direct anthropogenic sources of DIC within the Hooghly basin might account for only 2-3\% of the river water DIC concentrations. It remains unclear how much the biodegradation of organic $\mathrm{C}$ released from anthropogenic sources could contribute to downstream DIC generation and $\mathrm{CO}_{2}$ emissions in the Hooghly and other Indian estuaries.

The fact that in all three river systems $p \mathrm{CO}_{2}$ tended to be higher along lower reaches and tributaries than in headwater streams (Table 3; Fig. 4) might seem contradictory to the findings of some recent global syntheses that compared $p \mathrm{CO}_{2}$ levels between low-order streams and rivers (Lauerwald et al., 2015; Marx et al., 2017). These syntheses assumed that the stream $p \mathrm{CO}_{2}$ level might be determined by the relative contributions from terrestrial processes such as soil respiration and weathering and in-stream processes including biodegradation and photodegradation. It follows then that the contribution of terrestrially derived $p \mathrm{CO}_{2}$ may overwhelm the in-stream contribution, at least in low-order streams and rivers, resulting in a general trend of downstream decreases in $p \mathrm{CO}_{2}$. These assumptions, together with a finding of gradual downstream decline in the rate of the biodegra- dation of riverine $\mathrm{OM}$ due to an increasing dominance of recalcitrant components with increasing stream order and retention time (Catalán et al., 2016), are based on the river continuum concept and do not consider downstream variations in the consumption and replenishment of stream OM pools associated with enhanced algal production in impounded reaches and/or pulsatile inputs of anthropogenic OM delivered by urban streams as described in Fig. 2. In a global synthesis of data collected at 1182 sites, which did not include highly polluted river sites in Europe and the three Asian regions reviewed here, Lauerwald et al. (2015) found a slightly higher mean $p \mathrm{CO}_{2}(2471 \mu \mathrm{atm})$ in streams and small rivers compared to the mean value for large rivers $(2299 \mu \mathrm{atm})$. As Lauerwald et al. (2015) acknowledged, however, $p \mathrm{CO}_{2}$ may continue to increase along the lower reaches of large rivers in response to inputs of labile $\mathrm{OM}$ and dissolved $\mathrm{CO}_{2}$ from floodplains (Abril et al., 2014; Borges et al., 2015) and pollution sources in croplands and urban areas (Kempe, 1982; Frankignoulle et al., 1998). Although it is very difficult to evaluate the relative contributions of autochthonous, soil-derived, and anthropogenic OM fractions to enhanced biodegradation along lower reaches, some studies have examined the effects of domestic and industrial wastewater on the chemical composition and lability of organic $\mathrm{C}$ in the riverine and estuarine waters of some polluted Asian rivers (Guo et al., 2014; Samanta et al., 2015). By comparing fluorescence excitation-emission matrices (EEMs) of DOM between the branches and tributaries of the Yangtze River estuary, Guo et al. (2014) found that labile DOM components delivered by the Huangpu River, a highly polluted tributary, exerted a disproportionately large influence on the biodegradability of DOM in the Yangtze estuary. These chemical analyses, together with direct underway measurements that revealed extraordinarily high $p \mathrm{CO}_{2}$ levels along the polluted river and estuarine reaches of some Chinese rivers (Zhai et al., 2005; Chou et al., 2013; Wang et al., 2017), suggest that labile OM fractions of anthropogenic origin can boost the microbial processing of bulk riverine $\mathrm{OM}$, enhancing $\mathrm{CO}_{2}$ emissions from polluted waterways.

Unusually high $p \mathrm{CO}_{2}$ levels observed in some eutrophic rivers and estuaries across the three Asian regions cannot be explained by widely used metabolic continuum models that would be more relevant for rather "natural" inland water systems (Hotchkiss et al., 2015; Catalán et al., 2016). Many studies conducted in polluted European rivers reported frequent occurrences of extreme algal blooms and altered metabolic rates in the eutrophic reaches that had rarely been observed in flowing water systems under minimal to low human influences (Meybeck and Helmer, 1989; Hilton et al, 2006; Garnier and Billen, 2007). A recent report on $\mathrm{CO}_{2}$ outgassing from a highly urbanized river system in Korea suggested a potential regime shift in riverine metabolic processes by showing a shift in the relationship between Chl $a$ and $p \mathrm{CO}_{2}$ from the upstream reach less enriched in nutrients and $\mathrm{CO}_{2}$ to the eutrophic downstream reach receiving 


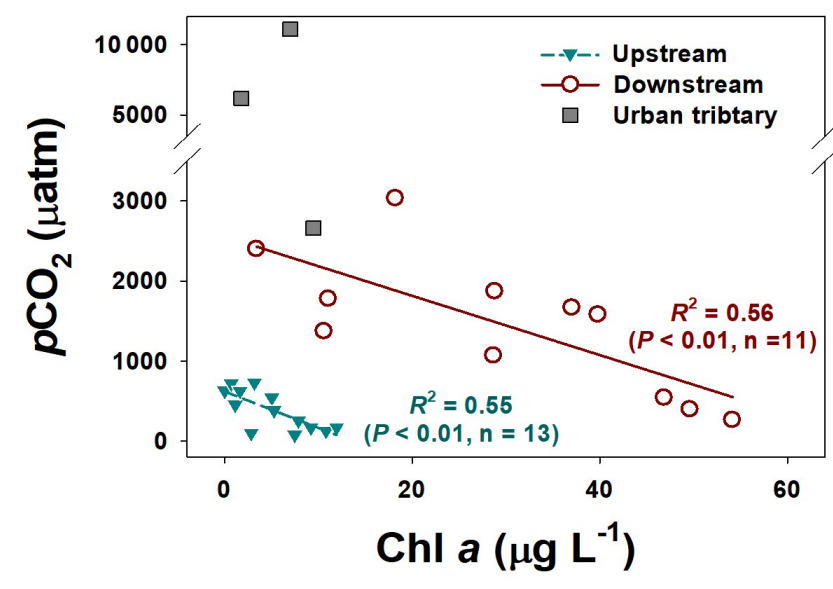

Figure 5. Longitudinal shift in the relationship between Chl $a$ and $p \mathrm{CO}_{2}$ observed between the upstream and downstream reaches of the Han River receiving highly polluted urban tributaries (modified from the Supplement of Yoon et al., 2017).

highly polluted urban tributaries carrying WWTP effluents (Yoon et al., 2017; Fig. 5). This case study was conducted in a heavily impounded and populated river basin (the Han River) where the middle reach is impounded by cascade dams and the lower reach receives loads of $\mathrm{OM}$ and nutrients delivered by urban streams draining the Seoul metropolitan area with a population $>20$ million. Therefore, multiple dams along the middle reach and pulsatile inputs of $\mathrm{OM}$ and nutrients along the lower reach may create discontinuities in metabolic processes and $\mathrm{CO}_{2}$ emissions along the longitudinally connected reaches, providing an excellent example of the anthropogenic land-water-scape depicted in Fig. 2. In accordance with the findings of large spatial and seasonal variations in the balance between autotrophy and heterotrophy in eutrophic European rivers (Garnier and Billen, 2007), the enhanced bacterial degradation of OM of both allochthonous and autochthonous origin in the eutrophic lower reach receiving high loads of organic pollutants might increase the level of $p \mathrm{CO}_{2}$ substantially despite the longitudinal increase in primary production with a widening channel toward the river mouth, shifting the regime of riverine metabolisms away from those found in the less eutrophic upstream reach (Fig. 5).

\section{Summary and future research needs}

This review identified alarming regional trends concerning dam construction booms and the rapid pace of urbanization across three reviewed Asian regions, both of which can significantly alter riverine metabolisms and $\mathrm{C}$ dynamics. Some recent studies have reported significant but contrasting impoundment effects on GHG emissions and sediment $\mathrm{C}$ storage in dammed rivers. As illustrated by large pulse emissions of $\mathrm{CO}_{2}$ and $\mathrm{CH}_{4}$ in the years following the construction of the Three Gorges Dam on the Yangtze River and cascade dams and the Nam Theun 2 in the lower Mekong River basin, flooded soils and vegetation can become major sources of GHGs during the initial years following dam construction. Long-term changes in GHG emissions and sediment C storage might vary with dam location, initial conditions of the flooded area, and land use changes occurring within the watersheds. As summarized in Table 3, there have been only a small number of $p \mathrm{CO}_{2}$ measurements in dammed Asian rivers and almost no study that tracked long-term changes in $\mathrm{CO}_{2}$ dynamics in impounded reaches and downstream rivers, making it very difficult to constrain the factors crucial for the spatial and temporal variations in $p \mathrm{CO}_{2}$ along the impounded reaches. Unlike in Europe and North America where very few large dam projects have been commissioned over recent decades, the current booms of mega-dam construction across Asia appear to induce ever-increasing perturbations to riverine $\mathrm{C}$ fluxes, demanding more systematic assessments of impoundment impacts on riverine organic $\mathrm{C}$ transport and GHG emissions. Specifically, these assessments require a basin-wide examination of temporal variations in the rates of primary production and organic matter biodegradation in line with $p \mathrm{CO}_{2}$ variations across impounded and upstream and downstream reaches along the "discontinuity distance" (Ward and Standford, 1983) to predict how impoundments alter the balance between autotrophy and heterotrophy and hence the air-water exchange of $\mathrm{CO}_{2}$ both in the short-term diel cycle and through seasonal and interannual variations. Long-term studies can also evaluate how frequent droughts associated with regional climate change can reverse the gradually decreasing GHG emissions from impounded river reaches through the enhanced decomposition of the $\mathrm{C}$ stored in the reservoir bottom sediment.

Although rapid urbanization across Asia is aggravating eutrophication and organic pollution in many large rivers draining metropolitan areas with a limited capacity for wastewater treatment infrastructure, the scarcity of high-quality monitoring data represents a huge challenge for a thorough assessment of the current status of riverine metabolisms and $\mathrm{CO}_{2}$ outgassing from the impacted rivers. Some exploratory studies conducted in highly urbanized watersheds in East Asia (e.g., Wang et al., 2017; Yoon et al., 2017) have questioned whether the conventional conceptual framework perceiving riverine $\mathrm{C}$ fluxes as a gradual longitudinal continuum can address the large cross-scale variations and pulsatile patterns of riverine $\mathrm{CO}_{2}$ outgassing observed in the highly modified river systems. Given the large share of the reviewed Asian regions ( $\sim 40 \%$ ) in global municipal wastewater production and disproportionately poor wastewater treatment infrastructure, it remains largely unknown whether our current understanding of biogeochemical processes in urban river systems in Europe and North America can help explain the idiosyncratic features of OM composition and turnover in streams and rivers contaminated with high loads of raw sewage and nutrients. Building on conceptual and mathematical models developed for highly eutrophic river sys- 
tems in Europe and North America (e.g., Garnier and Billen, 2007), we need to develop new integrative frameworks to explain river-specific responses to the unprecedented pace and scale of urbanization and water pollution. These integrative frameworks need to consider concurrent multiple environmental changes, including dams and climatic variability, and extreme events as confounding factors that can either boost or dampen pollution-induced pulses of $\mathrm{CO}_{2}$ emissions from highly polluted urban rivers. A key future challenge in predicting $\mathrm{CO}_{2}$ emissions from highly polluted, eutrophic river systems would be to constrain shifting balances between interrelated riverine metabolic processes, as illustrated by the regime shift in the relationship between Chl $a$ and $p \mathrm{CO}_{2}$ observed between the less impacted upstream and eutrophic downstream reaches of a highly urbanized river system (Fig. 5).

How to overcome the overall scarcity and spatially uneven availability of high-quality data, guided by an integrative conceptual framework reflecting observed regional trends, might be the number one research priority in providing a scientifically robust assessment of the current status of the human impacts on $\mathrm{C}$ fluxes in Asian river systems. Given the inadequate research capacity in many developing Asian countries, more efforts should be given to build collaborative research networks that can provide researchers with practical guides and standardized methodologies for designing and conducting field monitoring of riverine $\mathrm{C}$ fluxes at multiple spatial and temporal scales. These efforts need to pay more attention to emerging local issues in addition to the common regional patterns associated with river impoundment and pollution. As observed in the Tibetan Plateau, urbanization and dam construction have been expanding to the upstream headwater reaches of large rivers such as the Mekong, Yangtze, and Yellow River. The rapid expansion of anthropogenic perturbations, coupled with idiosyncratic local climates and ecosystems, can amplify changes in riverine metabolic processes and $\mathrm{C}$ dynamics. To better assess the interactive effects of concurrent multiple environmental changes and human-induced perturbations to the riverine networks of interacting land and water patches, we suggest that the long-standing concept of river continuum assuming "natural" states should be critically examined by field measurements and complemented with alternative perspectives of "discontinuity" or "discontinuous continuity" (sensu Poole, 2002) in riverine metabolisms and C fluxes created in impounded and eutrophic reaches of rivers draining increasingly urbanizing watersheds across Asia and globally.

Data availability. Data are available and can be requested from the corresponding author (jhp@ewha.ac.kr).

Author contributions. All authors contributed to data acquisition, the discussion of concepts and research topics, and paper prepa- ration. The paper was written through the concerted efforts of all authors and coordinated by JHP.

Competing interests. The authors declare that they have no conflict of interest.

Special issue statement. This article is part of the special issue "Human impacts on carbon fluxes in Asian river systems". It is not associated with a conference.

Acknowledgements. This work was supported by the Asia-Pacific Network for Global Change Research (CRRP2016-01MY-Park) and the National Foundation of Korea (2017R1D1A1B06035179). We thank Tae Kyung Yoon for providing a figure modified from the Supplement to his publication and Dr. Gwenaël Abril and two anonymous reviewers for proving insightful comments on the paper.

Edited by: Gwenaël Abril

Reviewed by: two anonymous referees

\section{References}

Abril, G., Guérin, F., Richard, S., Delmas, R., Galy-Lacaux, C., Gosse, P., Tremblay, A., Varfalvy, L., Dos Santos, M. A., and Matvienko, B.: Carbon dioxide and methane emissions and the carbon budget of a 10-year old tropical reservoir (Petit Saut, French Guiana), Global Biogeochem. Cy., 19, GB4007, https://doi.org/10.1029/2005GB002457, 2005.

Abril, G., Martinez, J.-M., Artigas L. F., Moreira-Turcq P., Benedetti M. F., Vidal L., Meziane T., Kim J.-H., Bernardes M. C., Savoye N., Deborde J., Albéric P., Souza M. F. L., Souza E. L., and Roland F.: Amazon River carbon dioxide outgassing fuelled by wetlands, Nature, 505, 395-398, https://doi.org/10.1038/nature12797, 2014.

Abril, G., Bouillon, S., Darchambeau, F., Teodoru, C. R., Marwick, T. R., Tamooh, F., Ochieng Omengo, F., Geeraert, N., Deirmendjian, L., Polsenaere, P., and Borges, A. V.: Technical Note: Large overestimation of $p \mathrm{CO}_{2}$ calculated from $\mathrm{pH}$ and alkalinity in acidic, organic-rich freshwaters, Biogeosciences, 12, 67-78, https://doi.org/10.5194/bg-12-67-2015, 2015.

Alin, S. R., Rasera, M. F. F. L., Salimon, C. I., Richey, J. E., Holtgrieve, G. W., Krusche, A. V., and Snidvongs, A.: Physical controls on carbon dioxide transfer velocity and flux in low-gradient river systems and implications for regional carbon budgets, J. Geophys. Res., 116, G01009, https://doi.org/10.1029/2010JG001398, 2011.

Allan, J. D.: Landscapes and riverscapes: The influence of land use on stream ecosystems, Annu. Rev. Ecol. Evol. S., 35, 257284, https://doi.org/10.1146/annurev.ecolsys.35.120202.110122, 2004.

Amann, T., Weiss, A., and Hartmann, J.: Carbon dynamics in the freshwater part of the Elbe estuary, Germany: Implications of improving water quality, Estuar. Coast. Shelf S., 107, 112-121, https://doi.org/10.1016/j.ecss.2012.05.012, 2012. 
Barros, N., Cole, J. J., Tranvik, L. J., Prairie, Y. T., Bastviken, D., Huszar, V. L. M., del Giorgio, P., and Roland, F.: Carbon emission from hydroelectric reservoirs linked to reservoir age and latitude, Nat. Geosci., 4, 593-596, https://doi.org/10.1038/ngeo1211, 2011.

Battin, T. J., Luyssaert, S., Kaplan, L. A., Aufdenkampe, A. K., Richter, A., and Tranvik, L. J.: The boundless carbon cycle, Nat. Geosci., 2, 598-600, https://doi.org/10.1038/ngeo618, 2009.

Baum, A., Rixen, T., and Samiaji, J.: Relevance of peat draining rivers in central Sumatra for the riverine input of dissolved organic carbon into the ocean, Estuar. Coast. Shelf S., 73, 563-570, https://doi.org/10.1016/j.ecss.2007.02.012, 2007.

Bhatt, M. P., McDowell, W. H., Gardner, K. H., and Hartmann, J.: Chemistry of the heavily urbanized Bagmati River system in Kathmandu Valley, Nepal: export of organic matter, nutrients, major ions, silica, and metals, Environ. Earth Sci., 71, 911-922, https://doi.org/10.1007/s12665-013-2494-9, 2014.

Bickle, M. J., Bunbury, J., Chapman, H. J., Harris, N. B. W., Fairchild, I. J., and Ahmed, T.: Fluxes of Sr into the headwaters of the Ganges, Geochim. Cosmochim. Ac., 67, 2567-2584, https://doi.org/10.1016/S0016-7037(03)00029-2, 2003.

Biswas, H., Mukhopadhyay, S. K., De, T. K., Sen, S., and Jana, T. K.: Biogenic controls on the air-water carbon dioxide exchange in the Sundarban mangrove environment, northeast coast of Bay of Bengal, India, Limnol. Oceanogr., 49, 95-101, https://doi.org/10.4319/1o.2004.49.1.0095, 2004.

Borges, A. V. and Abril, G.: Carbon dioxide and methane dynamics in estuaries, in: Treatise on Estuarine and Coastal Science, Volume 5, edited by: Wolanski, E. and McLusky, D., Academic Press, Waltham, 119-161, https://doi.org/10.1016/B9780-12-374711-2.00504-0, 2011.

Borges, A. V., Schiettecatte, L.-S., Abril, G., Delille, B., and Gazeau, F.: Carbon dioxide in European coastal waters, Estuar. Coast. Shelf S., 70, 375-387, https://doi.org/10.1016/j.ecss.2006.05.046, 2006.

Borges, A. V., Darchambeau, F., Teodoru, C. R., Marwick, T. R., Tamooh, F., Geeraert, N., Omengo, F. O., Guérin, F., Lambert, T., Morana, C., Okuku, E., and Bouillon, S.: Globally significant greenhouse gas emissions from African inland waters, Nat. Geosci., 8, 637-642, https://doi.org/10.1038/NGEO2486, 2015.

Borges, A. V., Abril, G., and Bouillon, S.: Carbon dynamics in the Mekong Delta, Biogeosciences, 15, 1093-1114, https://doi.org/10.5194/bg-15-1093-2018, 2018.

Butman, D. E., Wilson, H. F., Barnes, R. T., Xenopoulos, M. A., and Raymond, P. A.: Increased mobilization of aged carbon to rivers by human disturbance, Nat. Geosci., 8, 112-116, https://doi.org/10.1038/ngeo2322, 2015.

Cadenasso, M. L., Pickett, S. T., Groffman, P. M., Band, L. E., Brush, G. S., Galvin, M. F., Grove, J. M., Hagar, G., Marshall, V., McGrath, B. P., O'Neil-Dunne, J. P., Stack, W. P., and Troy, A. R.: Exchanges across land-water-scape boundaries in urban systems: strategies for reducing nitrate pollution, Ann. N. Y. Acad. Sci., 1134, 213-232, https://doi.org/10.1196/annals.1439.012, 2008.

Cai, W. J., Guo, X. H., Chen, C.-T. A., Dai, M. H., Zhang, L. J., Zhai, W. D., Lohrenz, S. E., Yin, K., Harrison, P. J., and Wang, Y. C.: A comparative overview of weathering intensity and $\mathrm{HCO}_{3}$ flux in the world's largest rivers with emphasis on the Changjiang, Huanghe, Zhujiang (Pearl) and Mississippi Rivers, Cont. Shelf Res., 28, 1538-1549, https://doi.org/10.1016/j.csr.2007.10.014, 2008.

Casas-Ruiz, J. P., Tittel, J., von Schiller, D., Catalán, N., Obrador, B., Gómez-Gener, L., Zwirnmann, E., Sabater, S., and Marce, R.: Drought-induced discontinuities in the source and degradation of dissolved organic matter in a Mediterranean river, Biogeochemistry, 127, 125-139, https://doi.org/10.1007/s10533-015-0173-5, 2016.

Catalán, N., Marcé R., Kothawala, D. N., and Tranvik, L. J.: Organic carbon decomposition rates controlled by water retention time across inland waters, Nat. Geosci., 9, 501-504, https://doi.org/10.1038/ngeo2720, 2016.

Chakrapani, G. J. and Veizer, J.: Dissolved inorganic carbon isotopic compositions in the Upstream Ganga river in the $\mathrm{Hi}-$ malayas, Curr. Sci., 89, 553-556, 2005.

Chen, H., Wu, Y., Yuan, X., Gao, Y., Wu, N., and Zhu, D.: Methane emissions from newly created marshes in the drawdown area of the Three Gorges Reservoir, J. Geophys. Res., 114, D18301, https://doi.org/10.1029/2009JD012410, 2009.

Chen, Y., Wang, K., Lin, Y., Shi, W., Song, Y., and He, X.: Balancing green and grain trade, Nat. Geosci., 8, 739-741, https://doi.org/10.1038/ngeo2544, 2015.

Chou, W.-C., Gong, G.-C., Cai, W.-J., and Tseng, C.-M.: Seasonality of $\mathrm{CO}_{2}$ in coastal oceans altered by increasing anthropogenic nutrient delivery from large rivers: evidence from the Changjiang-East China Sea system, Biogeosciences, 10, 38893899, https://doi.org/10.5194/bg-10-3889-2013, 2013.

Cole, J. J., Prairie, Y. T., Caraco, N. F., McDowell, W. H., Tranvik, L. J., Striegl, R. G., Duarte, C. M., Kortelainen, P., Downing, J. A., Middelburg, J. J., and Melack, J.: Plumbing the global carbon cycle: Integrating inland waters into the terrestrial carbon budget, Ecosystems, 10, 171-184, https://doi.org/10.1007/s10021006-9013-8, 2007.

Crawford, J. T., Loken, L. C., Stanley, E. H., Stets, E. G., Dornblaser, M. M., and Striegl, R. G.: Basin scale controls on $\mathrm{CO}_{2}$ and $\mathrm{CH}_{4}$ emissions from the Upper Mississippi River, Geophys. Res. Lett. 43, 1973-1979. https://doi.org/10.1002/2015GL067599, 2016.

Dai, M., Yin, Z., Meng, F., Liu, Q., and Cai, W.-J.: Spatial distribution of riverine DOC inputs to the ocean: an updated global synthesis, Curr. Opin. Environ. Sustain., 4, 170-178, https://doi.org/10.1016/j.cosust.2012.03.003, 2012.

Das, A. K.: Limno-chemistry of some Andhra Pradesh reservoirs, J. Inland Fish. Soc. India, 32, 37-44, 2000.

Degens, E. T., Kempe, S., and Richey, J. E.: Summary: biogeochemistry of major world river, in: Biogeochemistry of Major World Rivers, SCOPE Volume 42, edited by: Degens, E. T., Kempe, S., and Richey, J. E., 323-347, 1991.

Deshmukh, C., Serça, D., Delon, C., Tardif, R., Demarty, M., Jarnot, C., Meyerfeld, Y., Chanudet, V., Guédant, P., Rode, W., Descloux, S., and Guérin, F.: Physical controls on $\mathrm{CH}_{4}$ emissions from a newly flooded subtropical freshwater hydroelectric reservoir: Nam Theun 2, Biogeosciences, 11, 4251-4269, https://doi.org/10.5194/bg-11-4251-2014, 2016.

Deshmukh, C., Guérin, F., Vongkhamsao, A., Pighini, S., Oudone, P., Sopraseuth, S., Godon, A., Rode, W., Guédant, P., Oliva, P., Audry, S., Zouiten, C., Galy-Lacaux, C., Robain, H., Ribolzi, O., Kansal, A., Chanudet, V., Descloux, S., and Serça, D.: Carbon dioxide emissions from the flat bottom and shal- 
low Nam Theun 2 Reservoir: drawdown area as a neglected pathway to the atmosphere, Biogeosciences, 15, 1775-1794, https://doi.org/10.5194/bg-15-1775-2018, 2018.

Dutta, M. K., Mukherjee, R., Jana, T. K., and Mukhopadhyay, S. K.: Biogeochemical dynamics of exogenous methane in an estuary associated to a mangrove biosphere; the Sundarbans, NE coast of India, Mar. Chem., 170, 1-10, https://doi.org/10.1016/j.marchem.2014.12.006, 2015.

Ellis, E. E., Keil, R. G., Ingalls, A. E., and Richey, J. E.: Seasonal variability in the sources of particulate organic matter of the Mekong River as discerned by elemental and lignin analyses, J. Geophys. Res., 117, G01038, https://doi.org/10.1029/2011JG001816, 2012.

Evans, A. E. V., Hanjra, M. A., Jiang, Y., Qadir, M., and Drechsel, P.: Water quality: Assessment of the current situation in Asia, Int. J. Water Resour. Dev., 28, 195-216, https://doi.org/10.1080/07900627.2012.669520, 2012.

FAO (Food and Agriculture Organization): AQUASTAT http://www.fao.org/nr/water/aquastat/sets/index.stm, last access: 15 December 2017.

Feng, X., Fu, B., Lu, N., Zeng, Y., and Wu, B.: How ecological restoration alters ecosystem services: an analysis of carbon sequestration in China's Loess Plateau, Sci. Rep., 3, 2846, https://doi.org/10.1038/srep02846, 2013.

Frankignoulle, M., Abril, G., Borges, A., Bourge, I., Canon, C., Delille, B., Libert, E., and Théate, J.-M.: Carbon dioxide emission from European estuaries, Science, 282, 434-436, https://doi.org/10.1126/science.282.5388.434, 1998.

Galy, V., Peucker-Ehrenbrink, B., and Eglinton, T.: Global carbon export from the terrestrial biosphere controlled by erosion, $\mathrm{Na}$ ture, 521, 204-207, https://doi.org/10.1038/nature14400, 2015.

Garnier, J. and Billen, G.: Autotrophy and heterotrophy of aquatic communities in the Seine river system, Sci. Total Environ., 375, 110-124, 2007.

Griffith, D. R. and Raymond, P. A.: Multiple-source heterotrophy fueled by aged organic carbon in an urbanized estuary, Mar. Chem., 124, 14-22, https://doi.org/10.1016/j.marchem.2010.11.003, 2011.

Griffith, D. R., Barnes, R. T., and Raymond, P. A.: Inputs of fossil carbon from wastewater treatment plants to U.S. rivers and oceans, Environ. Sci. Technol., 43, 5647-5651, https://doi.org/10.1021/es9004043, 2009.

Grimm, N. B., Faeth, S. H., Golubiewski, N. E., Redman, C. L., Wu, J., Bai, X., and Briggs, J. M.: Global change and the ecology of cities, Science, 319, 756-760, https://doi.org/10.1126/science.1150195, 2008.

Grumbine, R. E., Dore, J., and Xu, J.: Mekong hydropower: drivers of change and governance challenges, Front. Ecol. Environ., 10, 91-98, https://doi.org/10.1890/110146, 2012.

Guo, W., Yang, L., Zhai, W., Chen, W., Osburn, C. L., Huang, X., and Li, Y.: Runoff-mediated seasonal oscillation in the dynamics of dissolved organic matter in different branches of a large bifurcated estuary - The Changiiang Estuary, J. Geophys. Res.Biogeo., 119, 776-793, https://doi.org/10.1002/2013JG002540, 2014.

Gupta, G. V. M., Thottathil, S. D., Balachandran, K. K., Madhu, N. V., Madeswaran, P., and Nair, S.: $\mathrm{CO}_{2}$ supersaturation and net heterotrophy in a tropical estuary (Cochin, India): In- fluence of anthropogenic effect, Ecosystems, 12, 1145-1157, https://doi.org/10.1007/s10021-009-9280-2, 2009.

Hartmann, J., Jansen, N., Kempe, S., and Dürr, H.: Geochemistry of the river Rhine and the upper Danube: Recent trends and lithological influence on baselines, J. Environ. Sci. Sustain. Soc., 1, 39-46, 2007.

Hartmann, J., Lauerwald, R., and Moosdorf, N.: A Brief Overview of the GLObal RIver Chemistry Database, GLORICH, Procedia Earth Planet. Sci., 10, 23-27, https://doi.org/10.1016/j.proeps.2014.08.005, 2014.

Hilton, J., O'Hare, M., Bowes, M. J., and Jones, J. I.: How green is my river? A new paradigm of eutrophication in rivers, Sci. Total Environ., 365, 66-83, https://doi.org/10.1016/j.scitotenv.2006.02.055, 2006.

Hosen, J. D., McDonough, O. T., Febria, C. M., and Palmer, M. A.: Dissolved organic matter quality and bioavailability changes across an urbanization gradient in headwater streams, Environ. Sci. Technol., 48, 7817-7824, https://doi.org/10.1021/es501422z, 2014.

Hotchkiss, E. R., Hall Jr., R. O., Sponseller, R. A., Butman, D., Klaminder, J., Laudon, H., Rosvall, M., and Karlsson, J.: Sources of and processes controlling $\mathrm{CO}_{2}$ emissions change with the size of streams and rivers, Nat. Geosci., 8, 696-699, https://doi.org/10.1038/ngeo2507, 2015.

$\mathrm{Hu}$, Y. and Cheng, H.: The urgency of assessing the greenhouse gas budgets of hydroelectric reservoirs in China, Nature Climate Change, 3, 708-712, https://doi.org/10.1038/nclimate1831, 2013.

Huang, X., Sillanpaa, M., Gjessing, E. T., Peraniemi, S., and Vogt, R. D.: Water quality in the southern Tibetan Plateau: chemical evaluation of the Yarlung Tsangpo (Brahmaputra), River Res. Applic., 27, 113-121, https://doi.org/10.1002/rra.1332, 2011.

Huang, T.-H., Fu, Y.-H., Pan, P.-Y., and Chen, C.-T. A.: Fluvial carbon fluxes in tropical rivers, Curr. Opin. Sust., 4, 162-169, https://doi.org/10.1016/j.cosust.2012.02.004, 2012.

Hynes, H. B. N.: The stream and its valley, Verh. Int. Ver. Theor. Angew. Limnol., 19, 1-15, https://doi.org/10.1080/03680770.1974.11896033, 1975.

Irvine, K. N, Murphy, T., Sampson, M., Dany, V., Vermette, S. J., and Tang, T.: An overview of water quality issues in Cambodia, Journal of Water Management Modeling R225-02, https://doi.org/10.14796/JWMM.R225-02, 2006.

Ittekkot, V.: Global trends in the nature of organic matter in river suspensions, Nature, 332, 436-438, https://doi.org/10.1038/332436a0, 1988.

Ittekkot, V., Safiullah, S., Mycke, B., and Seifert, R.: Seasonal variability and geochemical significance of organic matter in the River Ganges, Bangladesh, Nature, 317, 800-802, https://doi.org/10.1038/317800a0, 1985.

Jin, H., Yoon, T. K., Lee, S.-H., Kang, H., Im, J., and Park, J.H.: Enhanced greenhouse gas emission from exposed sediments along a hydroelectric reservoir during an extreme drought event, Environ. Res. Lett., 11, 124003, https://doi.org/10.1088/17489326/11/12/124003, 2016.

Joesoef, A., Huang, W.-J., Gao, Y., and Cai, W.-J.: Air-water fluxes and sources of carbon dioxide in the Delaware Estuary: spatial and seasonal variability, Biogeosciences, 12, 6085-6101, https://doi.org/10.5194/bg-12-6085-2015, 2015. 
Jung, B.-J., Lee, H.-J., Jeong, J.-J., Owen, J., Kim, B., Meusburger, K., Alewell, C., Gebauer, G., Shope, C., and Park, J.H.: Storm pulses and varying sources of hydrologic carbon export from a mountainous watershed, J. Hydrol., 440/441, 90-101, https://doi.org/10.1016/j.jhydrol.2012.03.030, 2012.

Kaushal, S. S. and Belt, K. T.: The urban watershed continuum: evolving spatial and temporal dimensions, Urban Ecosyst., 15, 409-435, https://doi.org/10.1007/s11252-012-0226-7, 2012.

Kaushal, S. S., McDowell, W. H., and Wollheim, W. M.: Tracking evolution of urban biogeochemical cycles: past, present, and future, Biogeochemistry, 121, 1-21, https://doi.org/10.1007/s10533-014-0014-y, 2014.

Kempe, S.: Long-term records of $\mathrm{CO}_{2}$ pressure fluctuations in fresh water, in: Transport of Carbon and Minerals in Major World Rivers Part 1, edited by: Degens, E. T., SCOPE/UNEP Sonderband 52, Mitt. Geol.-Paläont. Inst. Univ. Hamburg, Hamburg, 91-332, 1982.

Kempe, S.: Sinks of the anthropogenically enhanced carbon-cycle in surface fresh waters, J. Geophys. Res., 89, 4657-4676, https://doi.org/10.1029/JD089iD03p04657, 1984.

Koehler, B., von Wachenfeldt, E., Kothawala, D., and Tranvik, L. J.: Reactivity continuum of dissolved organic carbon decomposition in lake water, J. Geophys. Res., 117, G01024, https://doi.org/10.1029/2011JG001793, 2012.

Krishna, M. S., Prasad, M. H. K., Rao, D. B., Viswanadham, R., Sarma, V. V. S. S., and Reddy, N. P. C.: Export of dissolved inorganic nutrients to the northern Indian Ocean from the Indian monsoonal rivers during discharge period, Geochim. Cosmochim. Ac., 172, 430-443, https://doi.org/10.1016/j.gca.2015.10.013, 2015.

Labat, D., Goddéris, Y., Probst, J. L., and Guyot, J. L.: Evidence for global runoff increase related to climate warming, Adv. Water Resour., 27, 631-642, https://doi.org/10.1016/j.advwatres.2004.02.020, 2004.

Lauerwald, R., Laruelle, G. G., Hartmann, J., Ciais, P., and Regnier, P. A. G.: Spatial patterns in $\mathrm{CO}_{2}$ evasion from the global river network, Global Biogeochem. Cy., 29, 534-554, https://doi.org/10.1002/2014GB004941, 2015.

Le, T. P. Q., Marchand, C., Ho, C. T., Duong, T. T., Nguyen, H. T. M., XiXi, L., Vu, D. A., Doan, P. K., and Le, N. D.: $\mathrm{CO}_{2}$ partial pressure and $\mathrm{CO}_{2}$ emissions from the lower Red River (Vietnam), Biogeosciences Discuss., https://doi.org/10.5194/bg2017-505, in review, 2017.

Lehner, B., Liermann, C. R., Revenga, C., Vörösmarty, C., Fekete, B., Crouzet, P., Döll, P., Endejan, M., Frenken, K., Magome, J., Nilsson, C., Robertson, J. C., Rödel, R., Sindorf, N., and Wisser, D.: High-resolution mapping of the world's reservoirs and dams for sustainable river-flow management, Front. Ecol. Environ., 9, 494-502, https://doi.org/10.1890/100125, 2011.

Li, G., Xia, X., Yang, Z., Wang, R., and Voulvoulis, N.: Distribution and sources of polycyclic aromatic hydrocarbons in the middle and lower reaches of the Yellow River, China, Environ. Pollut., 144, 985-993, https://doi.org/10.1016/j.envpol.2006.01.047, 2006.

Li, S. and Bush, R. T.: Changing fluxes of carbon and other solutes from the Mekong River, Sci. Rep., 5, 16005, https://doi.org/10.1038/srep16005, 2015a.
Li, S. and Bush, R. T.: Revision of methane and carbon dioxide emissions from inland waters in India, Glob. Change Biol., 21, 6-8, https://doi.org/10.1111/gcb.12705, 2015b.

Li, S. Y., Lu, X. X., He, M., Zhou, Y., Li, L., and Ziegler, A. D.: Daily $\mathrm{CO}_{2}$ partial pressure and $\mathrm{CO}_{2}$ outgassing in the upper Yangtze River basin: a case study of the Longchuan River, China J. Hydrol., 466/467, 141-150, https://doi.org/10.1016/j.jhydrol.2012.08.011, 2012.

Li, J., Dong, S., Liu, S., Yang, Z., Peng, M., and Zhao, C.: Effects of cascading hydropower dams on the composition, biomass and biological integrity of phytoplankton assemblages in the middle Lancang-Mekong River, Ecol. Eng., 60, 316-324, https://doi.org/10.1016/j.ecoleng.2013.07.029, 2013a.

Li, S., Lu, X. X., and Bush, R. T.: $\mathrm{CO}_{2}$ partial pressure and $\mathrm{CO}_{2}$ emission in the Lower Mekong River, J. Hydrol., 504, 40-56, https://doi.org/10.1016/j.jhydrol.2013.09.024, 2013b.

Liu, S., Lu, X. X., Xia, X., Zhang, S., Ran, L., Yang, X., and Liu, T.: Dynamic biogeochemical controls on river $\mathrm{pCO}_{2}$ and recent changes under aggravating river impoundment: An example of the subtropical Yangtze River, Global Biogeochem. Cy., 30, 880 897, https://doi.org/10.1002/2016GB005388, 2016.

Lookingbill, T. R., Kaushal, S. S., Elmore, A. J., Gardner, R., Eshleman, K. N., Hilderbrand, R. H., Morgan, R. P., Boynton, W. R., Palmer, M. A., and Dennison, W. C.: Altered ecological flows blur boundaries in urbanizing watersheds, Ecol. Soc. 14, 10, https://doi.org/10.5751/ES-02989-140210, 2009.

Lu, Y., Song, S., Wang, R., Liu, Z., Meng, J., Sweetman, A. J., Jenkins, A., Ferrier, R. C., Li, H., and Luo, W.: Impacts of soil and water pollution on food safety and health risks in China, Environ. Int., 77, 5-15, https://doi.org/10.1016/j.envint.2014.12.010, 2015.

Ludwig, W., Probst, J.-L., and Kempe, S.: Predicting the oceanic input of organic carbon by continental erosion, Global Biogeochem. Cy., 10, 23-41, https://doi.org/10.1029/95GB02925, 1996.

Luthy, R. G., Sedlak, D. L., Plumlee, M. H., Austin, D., and Resh, V. H.: Wastewater-effluent-dominated streams as ecosystemmanagement tools in a drier climate, Front. Ecol. Environ., 13, 477-485, https://doi.org/10.1890/150038, 2015.

Maavara, T., Lauerwald, R., Regnier, P., and Van Cappellen, P.: Global perturbation of organic carbon cycling by river damming, Nat. Commun., 8, 15347, https://doi.org/10.1038/ncomms15347, 2017.

Manaka, T., Otani, S., Inamura, A., Suzuki, A., Aung, T., Roachanakanan, R., Ishiwa, T., and Kawahata, H.: Chemical weathering and long-term $\mathrm{CO}_{2}$ consumption in the Ayeyarwady and Mekong river basins in the Himalayas, J. Geophys. Res.-Biogeo., 120, 1165-1175, https://doi.org/10.1002/2015JG002932, 2015a.

Manaka, T., Ushie, H., Araoka, D., Otani, S., Inamura, A., Suzuki, A., Zakir Hossain, H. M., and Kawahata, H.: Spatial and Seasonal Variation in Surface Water $\mathrm{pCO}_{2}$ in the Ganges, Brahmaputra, and Meghna Rivers on the Indian Subcontinent, Aquat. Geochem., 21, 437-458, https://doi.org/10.1007/s10498015-9262-2, 2015b.

Martin, E. E., Ingalls, A. E., Richey, J. E., Keil, R. G., Santos, G. M., Truxal, L. T., Alin, S. R., and Druffel, E. R. M.: Age of riverine carbon suggests rapid export of terrestrial pri- 
mary production in tropics, Geophys. Res. Lett., 40, 5687-5691, https://doi.org/10.1002/2013GL057450, 2013.

Marx, A., Dusek, J., Jankovec, J., Sanda, M., Vogel, T., van Geldern, R., Hartmann, J., and Barth, J. A. C.: A review of $\mathrm{CO}_{2}$ and associated carbon dynamics in headwater streams: A global perspective, Rev. Geophys., 55, 560-585, https://doi.org/10.1002/2016RG000547, 2017.

Mateo-Sagasta, J., Raschid-Sally, L., and Thebo, A.: Global wastewater and sludge production, treatment and use, in: Wastewater-Economic Asset in an Urbanizing World, edited by: Drechsel, P., Qadir, M., and Wichelns, D., Springer, Dordrecht, 15-38, https://doi.org/10.1007/978-94-017-9545-6_2, 2015.

McCluney, K. E., Poff, N. L., Palmer, M. A., Thorp, J. H., Poole, G. C., Williams, B. S., Williams, M. R., and Baron, J. S.: Riverine macrosystems ecology: sensitivity, resistance, and resilience of whole river basins with human alterations, Front. Ecol. Environ., 12, 48-5, https://doi.org/10.1890/120367, 2014.

Meybeck, M. and Helmer, R.: The quality of rivers: From pristine stage to global pollution, Glob. Planet. Change, 1, 283-309, https://doi.org/10.1016/0921-8181(89)90007-6, 1989.

Milliman, J. D. and Farnsworth, K. L.: River Discharge to the Coastal Ocean: A Global Synthesis, Cambridge University Press, Cambridge, UK, 2011.

Milliman, J. D., Farnsworth, K. L., Jones, P. D., Xu, K. H., and Smith, L. C.: Climatic and anthropogenic factors affecting river discharge to the global ocean, 1951-2000, Glob. Planet. Change, 62, 187-194, https://doi.org/10.1016/j.gloplacha.2008.03.001, 2008.

Milly, P. C. D., Dunne, K. A., and Vecchia, A. V.: Global pattern of trends in streamflow and water availability in a changing climate, Nature, 438, 347-350, https://doi.org/10.1038/nature04312, 2005.

Min, S.-K., Zhang, X., Zwiers, F. W., and Hegerl, G. C.: Human contribution to more-intense precipitation extremes, Nature, 470, 378-381, https://doi.org/10.1038/nature09763, 2011.

Mosher, J. J., Kaplan, L. A., Podgorski, D. C., McKenna, A. M., and Marshall, A. G.: Longitudinal shifts in dissolved organic matter chemogeography and chemodiversity within headwater streams: a river continuum reprise, Biogeochemistry, 124, 371385, https://doi.org/10.1007/s10533-015-0103-6, 2015.

Mukhopadhyay, S. K., Biswas, H., De, T. K., Sen, S., and Jana, T. K.: Seasonal effects on the air-water carbon dioxide exchange in the Hooghly estuary, NE coast of Bay of Bengal, India, J. Environ. Monit., 4, 549-552, https://doi.org/10.1039/B201614A, 2002.

Palmer, M. A., Liermann, C. A. R., Nilsson, C., Flörke, M., Alcamo, J., Lake, P. S., and Bond, N.: Climate change and the world's river basins: anticipating management options, Front. Ecol. Environ., 6, 81-89, https://doi.org/10.1890/060148, 2008.

Panneer Selvam, B., Natchimuthu, S., Arunachalam, L., and Bastviken, D.: Methane and carbon dioxide emissions from inland waters in India - implications for large scale greenhouse gas balances, Glob. Change Biol., 20, 3397-3407, https://doi.org/10.1111/gcb.12575, 2014.

Park, J.-H., Duan, L., Kim, B., Mitchell, M. J., and Shibata, H.: Potential effects of climate change and variability on watershed biogeochemical processes and water quality in Northeast Asia, Environ. Int., 36, 212-225, https://doi.org/10.1016/j.envint.2009.10.008, 2010.
Park, J.-H., Inam, E., Abdullah, M. H., Agustiyani, D., Duan, L., Hoang, T. T., Kim, K.-W., Kim, S. D., Nguyen, M. H., Pekthong, T., Sao, V., Sarjiya, A., Savathvong, S., Sthiannopkao, S., Syers, J. K., and Wirojanagud, W.: Implications of rainfall variability for seasonality and climate-induced risks concerning surface water quality in East Asia, J. Hydrol., 400, 323-332, https://doi.org/10.1016/j.jhydrol.2011.01.050, 2011.

Paul, M. J. and Meyer, J. L.: Streams in the urban landscape, Annu. Rev. Ecol. Syst., 32, 333-365, https://doi.org/10.1146/annurev.ecolsys.32.081501.114040, 2001.

Pierrot, D., Lewis, E., and Wallace, D. W. R.: MS Excel Program developed for $\mathrm{CO}_{2}$ system calculations, ORNL/CDIAC-105a, Carbon dioxide Information Analysis Center, Oak Ridge National Laboratory, US Department of Energy, Oak Ridge, Tennessee, https://doi.org/10.3334/CDIAC/otg.CO2SYS_XLS_CDIAC105a, 2006.

Poole, G. C.: Fluvial landscape ecology: addressing uniqueness within the river discontinuum, Freshwater Biol., 47, 641-660, https://doi.org/10.1046/j.1365-2427.2002.00922.x, 2002.

Poole, G. C.: Stream hydrogeomorphology as a physical science basis for advances in stream ecology, J. North Am. Benthol. Soc., 29, 12-25, https://doi.org/10.1899/08-070.1, 2010.

Pradhan, U. K., Wu, Y., Shirodkar, P. V., Zhang, J., and Zhang, G.: Multi-proxy evidence for compositional change of organic matter in the largest tropical (peninsular) river basin of India, J. Hydrol., 519, 999-1009, https://doi.org/10.1016/j.jhydrol.2014.08.018, 2014.

Prasad, M. H. K., Sarma, V. V. S. S., Sarma, V. V., Krishna, M. S., and Reddy, N. P. C.: Carbon Dioxide Emissions from the Tropical Dowleiswaram Reservoir on the Godavari River, Southeast of India, J. Water Res. Prot., 5, 534-545, https://doi.org/10.4236/jwarp.2013, 2013.

Qu, B., Sillanpaa, M., Zhang, Y., Guo, J., Wahed, M. S. M. A., and Kang, S.: Water chemistry of the headwaters of the Yangtze River, Environ. Earth Sci., 74, 6443-6458, https://doi.org/10.1007/s12665-015-4174-4, 2015.

Qu, B., Zhang, Y., Kang, S., and Sillanpaa, M.: Water chemistry of the southern Tibetan Plateau: an assessment of the Yarlung Tsangpo river basin, Environ. Earth Sci., 76, 74, https://doi.org/10.1007/s12665-017-6393-3, 2017.

Ramesh, R. and Subramanian, V.: Temporal, spatial and size variation in sediment transport in the Krishna River Basin, India, J. Hydrol., 98, 53-65, https://doi.org/10.1016/00221694(88)90205-3, 1988.

Ramesh, R., Robin, R. S., and Purvaja, R.: An inventory on the phosphorus flux of major Indian rivers, Curr. Sci., 108, 1294 1299, 2015.

Ran, L., Lu, X. X., Sun, H., Han, J., Li, R., and Zhang, J.: Spatial and seasonal variability of organic carbon transport in the Yellow River, China, J. Hydrol., 498, 76-88, https://doi.org/10.1016/j.jhydrol.2013.06.018, 2013a.

Ran, L., Lu, X. X., Xin, Z., and Yang, X.: Cumulative sediment trapping by reservoirs in large river basins: A case study of the Yellow River basin, Glob. Planet. Change, 100, 308-319, https://doi.org/10.1016/j.gloplacha.2012.11.001, 2013 b.

Ran, L., Lu, X. X., and Xin, Z.: Erosion-induced massive organic carbon burial and carbon emission in the Yellow River basin 
China, Biogeosciences, 11, 945-959, https://doi.org/10.5194/bg11-945-2014, 2014.

Ran, L., Lu, X. X., Richey, J. E., Sun, H., Han, J., Liao, S., and Yi, Q.: Long-term spatial and temporal variation of $\mathrm{CO}_{2}$ partial pressure in the Yellow River, China, Biogeosciences, 12, 921932, https://doi.org/10.5194/bg-12-921-2015, 2015a.

Ran, L., Lu, X. X., Yang, H., Li, L., Yu, R., Sun, H., and Han, J.: $\mathrm{CO}_{2}$ outgassing from the Yellow River network and its implications for riverine carbon cycle, J. Geophys. Res.-Biogeo., 120, 1334-1347, https://doi.org/10.1002/2015JG002982, 2015b.

Ran, L., Li, L., Tian, M., Yang, X., Yu, R., Zhao, J., Wang, L., and $\mathrm{Lu}, \mathrm{X}$. X.: Riverine $\mathrm{CO}_{2}$ emissions in the Wuding River catchment on the Loess Plateau: Environmental controls and dam impoundment impact, J. Geophys. Res.-Biogeo., 122, 1439-1455, https://doi.org/10.1002/2016JG003713, 2017a.

Ran, L., Lu, X. X., and Liu, S.: Dynamics of riverine $\mathrm{CO}_{2}$ in the Yangtze River fluvial network and their implications for carbon evasion, Biogeosciences, 14, 2183-2198, https://doi.org/10.5194/bg-14-2183-2017, 2017b.

Raymond, P. A. and Spencer, R. G. M.: Riverine DOM, in: Biogeochemistry of Marine Dissolved Organic Matter, 2nd Edn., edited by: Hansell, D. A. and Carlson, C. A., Academic Press, Boston, 509-533, https://doi.org/10.1016/B978-012-405940-5.00011-X, 2015

Raymond, P. A., Hartmann, J., Lauerwald, R., Sobek, S., McDonald, C., Hoover, M., Butman, D., Striegl, R., Mayorga, E., Humborg, C., Kortelainen, P., Dürr, H., Meybeck, M., Ciais, P., and Guth, P.: Global carbon dioxide emissions from inland waters, Nature, 503, 355-359, https://doi.org/10.1038/nature12760, 2013.

Regnier, P., Friedlingstein, P., Ciais, P., Mackenzie, F. T., Gruber, N., Janssens, I. A., Laruelle, G. G., Lauerwald, R., Luyssaert, S., Andersson, A. J., Arndt, S., Arnosti, C., Borges, A. V., Dale, A. W., Gallego-Sala, A., Goddéris, Y., Goossens, N., Hartmann, J., Heinze, C., Ilyina, T., Joos, F., LaRowe, D. E., Leifeld, J., Meysman, F. J. R., Munhoven, G., Raymond, P. A., Spahni, R., Suntharalingam, P., and Thullner, M.: Anthropogenic perturbation of the carbon fluxes from land to ocean, Nat. Geosci., 6, 597-607, https://doi.org/10.1038/ngeo1830, 2013.

Samanta, S., Dalai, T. K., Pattanaik, J. K., Rai, S. K., and Mazumdar, A.: Dissolved inorganic carbon (DIC) and its $\delta^{13} \mathrm{C}$ in the Ganga (Hooghly) River estuary, India: Evidence of DIC generation via organic carbon degradation and carbonate dissolution, Geochim. Cosmochim. Ac., 165, 226-248, https://doi.org/10.1016/j.gca.2015.05.040, 2015.

Sarin, M. M., Krishnaswaswami, S., Dilli, K., Somayajulu, B. L. K., and Moore W. S.: Major ion chemistry of the GangaBrahmaputra river system: Weathering processes and fluxes to the Bay of Bengal, Geochim. Cosmochim. Ac., 53, 997-1009, https://doi.org/10.1016/0016-7037(89)90205-6, 1989.

Sarma, V. V. S. S., Kumar, N. A., Prasad, V. R., Venkataramana, V., Appalanaidu, S., Sridevi, B., Kumar, B. S. K., Bharati, M. D., Subbaiah, C. V., Acharyya, T., Rao, G. D., Viswanadham, R., Gawade, L., Manjary, D. T., Kumar, P. P., Rajeev, K., Reddy, N. P. C., Sarma, V. V., Kumar, M. D., Sadhuram, Y., and Murty, T. V. R.: High $\mathrm{CO}_{2}$ emissions from the tropical Godavari estuary (India) associated with monsoon river discharges, Geophys. Res. Lett., 38, L08601, https://doi.org/10.1029/2011GL046928, 2011.
Sarma, V. V. S. S., Viswanadham, R., Rao, G. D., Prasad, V. R., Kumar, B. S. K., Naidu, S. A., Kumar, N. A., Rao, D. B., Sridevi, T., Krishna, M. S. R., Reddy, N. P. C., Sadhuram, Y., and Murty, T. V. R.: Carbon dioxide emissions from Indian monsoonal estuaries, Geophys. Res. Lett., 39, L03602, https://doi.org/10.1029/2011GL050709, 2012.

Schlünz, B. and Schneider, R. R.: Transport of terrestrial organic carbon to the oceans by rivers: re-estimating flux- and burial rates, Int. J. Earth Sci., 88, 599-606, https://doi.org/10.1007/s005310050290, 2000.

Schmidt, C., Krauth, T., and Wagner, S.: Export of plastic debris by rivers into the sea, Environ. Sci. Technol., 51, 12246-12253, https://doi.org/10.1021/acs.est.7b02368, 2017.

Shi, W., Chen, Q., Yi, Q., Yu, J., Ji, Y., Hu, L., and Chen, Y.: Carbon emission from cascade reservoirs: Spatial heterogeneity and mechanisms, Environ. Sci. Technol., 51, 12175-12181, https://doi.org/10.1021/acs.est.7b03590, 2017.

Stanford, J. A. and Ward, J. V.: Revisiting the serial discontinuity concept, River Res. Appl., 17, 303-310, https://doi.org/10.1002/rrr.659, 2001.

Stanley, E. H., Powers, S. M., Lottig, N. R., Buffam, I., and Crawford, J. T.: Contemporary changes in dissolved organic carbon (DOC) in human-dominated rivers: is there a role for DOC management?, Freshwater Biol., 57, 26-42, https://doi.org/10.1111/j.1365-2427.2011.02613.x, 2011.

Syvitski, J. P. M., Vörösmarty, C. J., Kettner, A. J., and Green, P.: Impact of humans on the flux of terrestrial sediment to the global coastal ocean, Science, 308, 376-380, https://doi.org/10.1126/science.1109454, 2005.

Townsend, C. R.: Concepts in river ecology: pattern and process in the catchment hierarchy, Arch. Hydrobiol., 113, 3-21, https://doi.org/10.1127/lr/10/1996/3, 1996.

Vannote, R. L., Minshall, G. W., Cummins, K. W., Sedell, J. R., and Cushing, C. E.: The river continuum concept, Can. J. Fish. Aquat. Sci., 37, 130-137, https://doi.org/10.1139/f80-017, 1980.

Wang, S., Fu, B., Piao, S., Lü, Y., Ciais, P., Feng, X., and Wang, W.: Reduced sediment transport in the Yellow River due to anthropogenic changes, Nat. Geosci., 9, 38-41, https://doi.org/10.1038/ngeo2602, 2015.

Wang, X., He, Y., Yuan, X., Chen, H., Peng, C., Zhu, Q., Yue, J., Ren, H., Deng, W., and Liu, H.: $p \mathrm{CO}_{2}$ and $\mathrm{CO}_{2}$ fluxes of the metropolitan river network in relation to the urbanization of Chongqing, China, J. Geophys. Res.-Biogeo., 122, 470-486, https://doi.org/10.1002/2016JG003494, 2017.

Ward, J. V. and Stanford, J. A.: Serial discontinuity concept of lotic ecosystems, in: Dynamics of Lotic Systems, edited by: Fontaine, T. D. and Bartell, S. M., Ann Arbor Science, Ann Arbor, 29-42, 1983.

Ward, N. D., Bianchi, T. S., Medeiros, P. M., Seidel, M., Richey, J. E., Keil, R. G., and Sawakuchi, H. O.: Where Carbon Goes When Water Flows: Carbon Cycling across the Aquatic Continuum, Front. Mar. Sci., 4, 7, https://doi.org/10.3389/fmars.2017.00007, 2017.

Webster, J. R.: Spiraling down the river continuum: stream ecology and the U-shaped curve, J. N. Am. Benthol. Soc., 26, 375-389, https://doi.org/10.1899/06-095.1, 2007.

Wehrli, B.: Conduits of the carbon cycle, Nature, 503, 346-347, https://doi.org/10.1038/503346a, 2013. 
Weyhenmeyer, G. A., Fröberg, M., Karltun, E., Khalili, M., Kothawala, D., Temnerud, J., and Tranvik, L. J.: Selective decay of terrestrial organic carbon during transport from land to sea, Glob. Change Biol., 18, 349-355, https://doi.org/10.1111/j.13652486.2011.02544.x, 2012.

Winemiller, K. O., McIntyre, P. B., Castello, L., Fluet-Chouinard, E., Giarrizzo, T., Nam, S., Baird, I. G., Darwall, W., Lujan, N. K., Harrison, I., Stiassny, M. L. J., Silvano, R. A. M., Fitzgerald, D. B., Pelicice, F. M., Agostinho, A. A., Gomes, L. C., Albert, J. S., Baran, E., Petrere Jr., M., Zarfl, C., Mulligan, M., Sullivan, J. P., Arantes, C. C., Sousa, L. M., Koning, A. A., Hoeinghaus, D. J., Sabaj, M., Lundberg, J. G., Armbruster, J., Thieme, M. L., Petry, P., Zuanon, J., Torrente Vilara, G., Snoeks, J., Ou, C., Rainboth, W., Pavanelli, C. S., Akama, A., van Soesbergen, A., and Sáenz, L.: Balancing hydropower and biodiversity in the Amazon, Congo, and Mekong, Science, 351, 128-129, https://doi.org/10.1126/science.aac7082, 2016.

Wit, F., Muller, D., Baum, A., Warneke, T., Pranowo, W. S., Muller, M., and Rixen, T.: The impact of disturbed peatlands on river outgassing in Southeast Asia, Nat. Commun., 6, 10155, https://doi.org/10.1038/ncomms10155, 2015.

Yao, G., Gao, Q., Wang, Z., Huang, X., He, T., Zhang, Y., Jiao, S., and Ding, J.: Dynamics of $\mathrm{CO}_{2}$ partial pressure and $\mathrm{CO}_{2}$ outgassing in the lower reaches of the Xijiang River, a subtropical monsoon river in China, Sci. Total Environ., 376, 255-266, https://doi.org/10.1016/j.scitotenv.2007.01.080, 2007.

Yoon, T. K., Jin, H., Oh, N.-H., and Park, J.-H.: Technical note: Assessing gas equilibration systems for continuous $p \mathrm{CO}_{2}$ measurements in inland waters, Biogeosciences, 13, 3915-3930, https://doi.org/10.5194/bg-13-3915-2016, 2016.
Yoon, T. K., Jin, H., Begum, M. S., Kang, N., and Park, J.-H.: $\mathrm{CO}_{2}$ outgassing from an urbanized river system fueled by wastewater treatment plant effluents, Environ. Sci. Technol., 51, 1045910467, https://doi.org/10.1021/acs.est.7b02344, 2017.

Zhai, W., Dai, M., Cai, W. J., Wang, Y., and Wang, Z.: High partial pressure of $\mathrm{CO}_{2}$ and its maintaining mechanism in a subtropical estuary: The Pearl River estuary, China, Mar. Chem., 93, 21-32, https://doi.org/10.1016/j.marchem.2004.07.003, 2005.

Zhang, H., Liu, S., Yuan, W., Dong, W., Xia, J., Cao, Y., and Jia, Y.: Loess Plateau check dams can potentially sequester eroded soil organic carbon, J. Geophys. Res.-Biogeo., 121, 1449-1455, https://doi.org/10.1002/2016JG003348, 2016.

Zhang, S., Lu, X. X., Sun, H., Han, J., and Higgitt, D. L.: Major ion chemistry and dissolved inorganic carbon cycling in a humandisturbed mountainous river (the Luodingjiang River) of the Zhujiang (Pearl River), China, Sci. Tot. Environ., 407, 2796-2807, https://doi.org/10.1016/j.scitotenv.2008.12.036, 2009.

Zhang, S. R., Lu, X. X., Higgitt, D. L., Chen, C. T. A., Sun, H. G., and Han, J. T.: Water chemistry of the Zhujiang (Pearl River): Natural processes and anthropogenic influences, J. Geophys. Res.-Earth, 112, F01011, https://doi.org/10.1029/2006JF000493, 2007.

Zhang, L. J., Wang, L., Cai, W.-J., Liu, D. M., and Yu, Z. G.: Impact of human activities on organic carbon transport in the Yellow River, Biogeosciences, 10, 2513-2524, https://doi.org/10.5194/bg-10-2513-2013, 2013.

Zou, J.: Sources and dynamics of inorganic carbon within the upper reaches of the Xi River basin, Southwest China, PLoS ONE, 11, e0160964, https://doi.org/10.1371/journal.pone.0160964, 2016. 